PONTIFÍCIA UNIVERSIDADE CATÓLICA do RIO dE JANEIRO

\title{
Avaliação de ações educacionais em Educação Corporativa: um estudo de caso na Universidade Petrobras
}

\author{
Jéssica Gomes Santos
}

Trabalho de Conclusão de Curso

Centro de CIÊNCIAS SOCIAIS - CCS

DePARTAMENTO de AdMINISTRAÇÃo

Graduação em Administração de Empresas 
Jéssica Gomes Santos

Avaliação de ações educacionais em Educação Corporativa: um estudo de caso na Universidade Petrobras

Trabalho de Conclusão de Curso, apresentado ao programa de graduação em Administração da PUC-Rio como requisito parcial para a obtenção do título de graduação em Administração.

Orientador(a) : Patricia Itala Ferreira

Rio de Janeiro

Junho de 2016. 
"O conhecimento e a informação são os recursos estratégicos para o desenvolvimento de qualquer país. Os portadores desses recursos são as pessoas. "

(Peter Drucker) 


\section{Agradecimentos}

A Deus, que me possibilitou a realização de um sonho e me deu oportunidade de atingir meus objetivos.

À minha mãe, Marizete Gomes, que sempre me apoiou, esteve ao meu lado nos momentos mais difíceis e me motivou a dar sempre o meu melhor e nunca desistir de lutar.

Ao meu namorado, Luiz Felipe do Carmo, que me motivou durante toda essa caminhada e esteve comigo para compartilhar os momentos de alegria e tristeza.

À minha família por todo o apoio e lealdade disponibilizados nessa caminhada.

Aos meus amigos de faculdade, com os quais compartilhei o aprendizado, as dificuldades, e os momentos vivenciados na PUC.

Aos meus professores, por terem compartilhado o conhecimento que fizeram eu me tornar uma profissional.

À minha orientadora Patricia Itala Ferreira, que me ajudou a tornar esse trabalho uma realidade. Muito obrigada por sua orientação, comprometimento e suporte. 


\section{Resumo}

Gomes Santos, Jéssica. Avaliação de ações educacionais em Educação Corporativa: um estudo de caso na Universidade Petrobras. Rio de Janeiro, 2016. p.81. Trabalho de Conclusão de Curso - Departamento de Administração. Pontifícia Universidade Católica do Rio de Janeiro.

O objetivo desse estudo é identificar e analisar o processo de avaliação das ações educacionais da Universidade Corporativa da Petrobras. Para isso, realizou-se uma pesquisa bibliográfica, abordando diversos modelos de avaliação e, de maneira mais detalhada, a avaliação dos quatro níveis de Kirkpatrick. Houve também pesquisa documental e de campo, por meio da análise dos documentos empresariais e da realização de entrevista com responsáveis pela aplicação das avaliações dos programas de treinamento. Um resultado importante do presente estudo foi identificar que a organização possui um processo de avaliação aderente aos três primeiros níveis de Kirkpatrick (2010).

Palavras- chave: Educação Corporativa; Universidade Corporativa; Avaliação de educação corporativa

\section{Abstract}

Gomes Santos, Jéssica. Evaluating Corporate Education programs: a case study in a Petrobras University. Rio de Janeiro, 2016. p.81. Trabalho de Conclusão de Curso - Departamento de Administração. Pontifícia Universidade Católica do Rio de Janeiro.

The purpose of this study is to identify and analyze the evaluation of the Petrobras Corporate University. To do this, we've performed a literature search, addressing several theories on evaluation models, more deeply, the Kirkpatrick's Four-Level Training Evaluation Model. There was also a documentary research and a field research, through the analysis of some company's documents and focused Interviews, with responsible employee for application evaluations of training programs. The main results obtained in this study address that the company has the first tree level of Kirkpatrick's model.

Key-words: Corporate Education; Corporate University; Evaluating Corporate Education 


\section{Sumário}

1 O tema e o problema de estudo 1

1.1. Introdução ao tema e ao problema do estudo 1

1.2. Objetivo do estudo 3

1.3. Objetivos intermediários do estudo 3

1.4. Delimitação e foco do estudo 3

1.5. Justificativa e relevância do estudo 4

2 Revisão de literatura 5

2.1. Treinamento e Desenvolvimento 5

2.2. Universidade Corporativa 9

2.2.1. Histórico 9

2.3. Avaliação em educação corporativa 13

2.3.1. Modelos de Avaliação de Treinamento 16

2.3.1.1. Modelo de Kirkpatrick 16

2.3.1.2. Modelo de Phillips 19

2.3.1.3. Modelo de Hamblin $\quad 21$

2.3.1.4. Modelo de Palmeira 23

2.3.1.5. Modelo de Borges-Andrade 23

2.3.1.6. Modelo de Allen e McGee 25

$\begin{array}{ll}\text { 2.4. Indicadores } & 27\end{array}$

2.4.1. Indicadores de treinamento 29

2.4.1.1. Participação das despesas de treinamento no lucro 29

2.4.1.2. Custo de treinamento por empregado 29

2.4.1.3. Hora de treinamento pelo número de empregados 30

2.4.1.4. Índice de empregados em programas de treinamento 31

2.4.1.5. Prontidão dos líderes 31

2.4.1.6. Tipo de treinamento versus total de treinamento 32

2.4.1.7. Vagas disponibilizadas versus demanda planejada 32

2.4.1.8. Vagas oferecidas versus utilizadas 32

3 Métodos e procedimentos de coleta e de análise de dados do estudo 33 
3.1. Instrumentos de coleta de dados e forma de análise

4 Apresentação e análise dos resultados

4.1. A Empresa

4.2. Descrição e análise dos resultados

4.2.1. Levantamento da necessidade de treinamento

4.2.2. Programas educacionais

4.2.3. Avaliação das ações educacionais $\quad 44$

4.2.3.1. Avaliação de Reação 44

4.2.3.2. Avaliação de Aprendizagem 46

4.2.3.3. Avaliação de Impacto 47

4.2.3.4. Indicadores $\quad 52$

4.2.3.5. Necessidade de avaliar ações educacionais $\quad 54$

4.2.3.6. Resultados das avaliações $\quad 54$

5 Conclusões e recomendações para novos estudos 56

5.1. Sugestões e recomendações para novos estudos 59

6 Referências Bibliográficas $\quad 60$

Apêndice 1 - Roteiro de entrevista - Gerente 62

Apêndice 2 - Roteiro de entrevista - Equipe Impacto 64

Anexo 1 - Formulário de Avaliação de Reação 65

Anexo 2 - Questionário de impacto para participante 66

Anexo 3 - Questionário de impacto para Gerentes 71

Anexo 4 - Avaliação de Impacto - Infográfico 73 


\section{Lista de figuras}

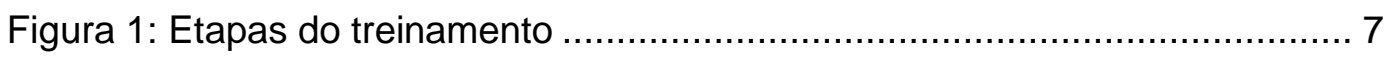

Figura 2: Modelo de Hamblin ................................................................ 22

Figura 3: Modelo de Palmeira ..................................................................... 23

Figura 4: Modelo MAIS de Borges-Andrade ................................................. 24

Figura 5: Modelo de Produtividade - Allen e McGee..................................... 26

Figura 6: Ciclo de busca de melhorias práticas ............................................... 28

Figura 7: Organização da Universidade Petrobras ......................................... 38

Figura 8: Sistema de DRH........................................................................ 41

\section{Lista de Tabelas}

Tabela 1: Comparação entre as principais metodologias ............................... 15

Tabela 2: Tabela de indicadores da Petrobras ............................................ 53 


\section{0 tema e o problema de estudo}

\subsection{Introdução ao tema e ao problema do estudo}

A educação sempre foi vista como um fator fundamental no desenvolvimento da sociedade. No século XXI, ela se tornou um instrumento necessário às mudanças crescentes e no desenvolvimento do país. Acrescentou-se à educação a responsabilidade de fomentar o crescimento econômico, agindo paralelamente no desenvolvimento de novos conhecimentos e tecnologias e na preparação e aprimoramento da força de trabalho. (PEREIRA, 2004; EBOLI, 2010)

A formação dos empregados nas organizações é um tema presente desde a Revolução Industrial. Inicialmente o objetivo era preparar indivíduos para realizarem suas tarefas. Com o decorrer do tempo, veio a preocupação de não só treinar essas pessoas, mas também desenvolvê-las para assumir um outro cargo no futuro. A partir do século $X X$, começou-se a perceber rápidas transformações do ambiente e as organizações foram forçadas a se adaptarem e, consequentemente, as ações educacionais também foram impactadas. (DIAS, GUEDES, 2013; EBOLI, 2010; PEREIRA, 2004)

Segundo Eboli (2010), na Era do Conhecimento a base geradora de riqueza das nações será constituída por sua organização social e pelo seu conhecimento criador. Diante da incerteza do mundo atual, que requer rapidez na tomada de decisão e flexibilidade, a informação e o conhecimento se tornaram recursos fundamentais e estratégicos.

Diante desse contexto o conceito de educação corporativa passa a ser 0 foco para formação dos profissionais. Nessa nova atuação, a aprendizagem não está mais restrita à sala de aula de universidades e colégios, mas permeia e ocupa vários espaços. A aprendizagem se torna contínua. (PEREIRA, 2004)

A educação corporativa é mais abrangente do que treinamento e desenvolvimento, pois é centrada no desenvolvimento de talentos e redireciona 
a aprendizagem para atingir as metas estratégicas e melhorias do desempenho empresarial. (LOPES, 2005)

Os programas educacionais nas empresas sempre existiram, mas normalmente eram restritos aos níveis gerenciais e à alta administração; para a grande maioria havia programas de treinamento pontuais para realização de determinada tarefa. (EBOLI, 2010) As Universidades Corporativas acabaram com esse paradigma e trouxeram a preocupação de educação para todos os colaboradores da empresa.

Dessa forma, faz-se interessante mensurar o quanto os cursos oferecidos por essas universidades têm contribuído para atingir o objetivo final, ou qual o retorno dos investimentos no desempenho dos funcionários, ou até mesmo qual o retorno organizacional derivados dos cursos oferecidos.

O objeto desse estudo é a Universidade Corporativa da Petrobras, contemplando o processo de ações educacionais, desde o levantamento da necessidade de treinamento, o método avaliação dessas ações, os resultados provenientes e seus indicadores e metas empresariais.

A Universidade Petrobras (UP) foi criada em 2000, após uma redefinição dos treinamentos oferecidos, e a extinção do seu Centro de Treinamento (CT) e Desenvolvimento. Essa mudança foi ocasionada a fim de aumentar a competitividade da companhia e redução das perdas de mercado.

A UP determina, através da estratégia definida no plano de negócios, os cursos a serem oferecidos no período subsequente. Em seguida, juntamente com os funcionários, os gestores identificam as necessidades de ações educacionais, a fim de suprir as carências que impossibilitam o alcance das metas organizacionais.

Nas ações educacionais, a UP preza pelo alinhamento das soluções educacionais aos planos de negócios e gestão da companhia; a qualidade na disseminação do conhecimento; a otimização e disciplina no uso dos recursos; e a adoção de processos simplificados e aperfeiçoados continuamente. Metas e indicadores de desempenho fazem parte dessa realidade.

O desafio atual da UP é oferecer ações de educação, com qualidade, aos profissionais, verificando os reflexos do aprendizado na prática e o atingimento das estratégias organizacionais. Dessa forma, uma preocupação é como avaliar as ações educacionais, a fim de obter as informações necessárias para a gestão empresarial. 
A partir de todo o exposto, o presente trabalho tem como finalidade responder aos seguintes questionamentos: Como a Universidade Corporativa Petrobras avalia seus programas de educação corporativa? Que sugestões podem ser dadas para contribuir com a melhoria deste processo?

\subsection{Objetivo do estudo}

O objetivo final desse estudo é identificar e analisar o processo de avaliação de educação corporativa da Universidade Corporativa da Petrobras, apontando oportunidade de melhorias.

\subsection{Objetivos intermediários do estudo}

A fim de atingir o objetivo proposto, esse estudo prevê como objetivos intermediários:

$\checkmark$ Conceituar o que é uma Universidade Corporativa;

$\checkmark$ Apresentar os principais modelos de avaliação de treinamento;

$\checkmark$ Apresentar a importância de um modelo de avaliação de ações educacionais para uma educação corporativa;

$\checkmark$ Identificar o levantamento de necessidade de treinamento da Universidade Petrobras;

$\checkmark$ Descrever o sistema de avaliação da educação corporativa da organização estudada.

\subsection{Delimitação e foco do estudo}

O presente estudo foi realizado na Universidade Petrobras, localizada na cidade do Rio de Janeiro. Foram realizadas entrevistas com o Gerente setorial de Processos Corporativos de Desenvolvimento de Recursos Humanos na Universidade Petrobras e com a equipe que realiza a avaliação de impacto, composta por uma coordenadora, uma analista e uma estagiária. Buscou-se entender como é feito o processo de avaliação, com que frequência ele é aplicado; como os resultados dessas avaliações influenciam na manutenção e melhoria dos cursos oferecidos; e como se identifica a mudança no desempenho dos colaboradores egressos dos cursos. As entrevistas ocorreram em Março e Abril de 2016. 
Embora relevante, não se pretende quantificar o retorno financeiro que a instituição obtém a partir das suas ações de treinamento. Tal perspectiva demandaria uma análise financeira, que não é o propósito desse trabalho.

\subsection{Justificativa e relevância do estudo}

Os programas educacionais ofertados, em uma educação corporativa, devem estar alinhados ao direcionamento estratégico da empresa. A avaliação desses programas possibilita averiguar o alinhamento, ou não, dos cursos aos objetivos organizacionais. Além disso, essa avaliação também apresenta os resultados alcançados, para o profissional e para a empresa, a partir das ações educacionais e sua relação de custo e benefício. Isso pode ser um subsídio para tomada de decisões de manutenção, extinção ou melhoria dos cursos oferecidos.

O presente trabalho pode ser útil para a empresa estudada, já que tem como objetivo a análise e a sugestão de melhoria do modelo atual de avaliação de programas educacionais. Assim, o estudo pode servir para consulta e revisão do modelo de avaliação utilizado na Universidade Corporativa.

As organizações que queiram implantar um modelo de avaliação de ações educacionais podem utilizar as informações aqui produzidas como uma de suas fontes de informação. Além disso, pode se inspirar no estudo de caso abordado e nas propostas de melhoria apresentadas, para definir o melhor método de avaliação para sua organização.

Por fim, também é importante para o campo acadêmico, pois, além de aumentar a produção textual referente ao tema estudado, os resultados alcançados podem auxiliar o embasamento e direcionamento de estudos futuros. 


\section{Revisão de literatura}

Neste capítulo são apresentados e discutidos aspectos conceituais e pesquisas relacionadas ao tema e estudo em investigação, que servirão de base para a análise realizada.

Esta seção está dividida em quatro partes e abordam, respectivamente, a conceituação do treinamento e desenvolvimento, a contextualização e definição de educação corporativa, a apresentação das metodologias de mensuração das avaliações de treinamento e os indicadores das ações de treinamento.

\subsection{Treinamento e Desenvolvimento}

O treinamento é o processo que possibilita 0 aprendizado de conhecimento, atitudes e habilidades em função de objetivos definidos. "O treinamento envolve a transmissão de conhecimentos específicos relativos ao trabalho, atitudes frente a aspectos da organização, da tarefa e do ambiente, e desenvolvimento de habilidades." (CHIAVENATO, 2002, p. 497)

O treinamento de pessoas é uma tarefa que tem grande importância desde o início do século XX, influenciado pela administração clássica. O objetivo dessa prática era preparar o indivíduo para atingir o maior grau de produtividade possível. A partir da década de 60 , com a adoção do enfoque sistêmico pela Administração de Recursos Humanos, o treinamento começou a envolver atividades voltadas para o suprimento das carências do indivíduo, em termos de conhecimento, habilidades e atitudes com o intuito de desempenhar as tarefas necessárias para alcançar os objetivos organizacionais. (GIL, 2007).

Atualmente, o treinamento e o desenvolvimento são processos contínuos, que visam o aperfeiçoamento do profissional e sua imersão com a cultura e os objetivos organizacionais. O aprendizado se tornou mais acessível e já há empresas que adotam treinamentos online como forma de redução de custos, já que o profissional vai acessar o conteúdo pela intranet da empresa; e acessibilidade para realização do curso em qualquer local, por mais que esteja geograficamente distante, e no melhor horário para o funcionário. (CHIAVENATO, 2002; GIL, 2007) 
Segundo Pereira (2004), há uma tendência em relacionar treinamento a um processo de aquisição ou aperfeiçoamento do conhecimento, habilidades e mudanças de atitude, particularmente envolvidas para a execução de uma tarefa ou de um cargo. Já desenvolvimento é um processo voltado para o crescimento integral do homem, observável na mudança de comportamento, na expansão das habilidades e dos conhecimentos, para criação de novas e diferentes soluções de problemas.

Dessa forma, o treinamento é uma educação para adaptar o profissional a um cargo; já o desenvolvimento é a educação que desenvolve e aperfeiçoa o profissional em uma determinada carreira ou para que seja mais eficiente no cargo. Contudo esses dois fatores, treinamento e desenvolvimento, devem atuar em conjunto, devem ser mutuamente complementares. (PEREIRA, 2004)

"O treinamento é uma fonte de lucratividade ao permitir que as pessoas contribuam efetivamente para os resultados do negócio." (CHIAVENATO, 2002, p.367). Ele enriquece o patrimônio humano das organizações, por favorecer o desenvolvimento de competências dos profissionais, o que os torna mais produtivos, criativos e inovadores. Esse desenvolvimento contribui para que sejam atingidos os objetivos da organização. (CHIAVENATO, 2002).

Segundo Chiavenato (2009), os principais objetivos do treinamento são: preparar as pessoas para a execução das diversas tarefas do cargo; proporcionar oportunidades para o contínuo desenvolvimento pessoal, visando à atuação em funções mais complexas e elevadas e; mudar a atitude das pessoas seja para criar um clima satisfatório entre elas, ou, para torná-las mais receptivas às novas técnicas de gestão.

Treinamento é o ato intencional de fornecer os meios para possibilitar a aprendizagem. Aprendizagem é um fenômeno que surge como resultado dos esforços de cada indivíduo. A aprendizagem é uma mudança no comportamento e ocorre no dia a dia e em todos os indivíduos. O treinamento deve tentar orientar essas experiências de aprendizagem num sentido positivo e benéfico e suplementá-las e reforçá-las com atividade planejada, a fim de que os indivíduos em todos os níveis da empresa possam desenvolver mais rapidamente seus conhecimentos e aquelas atitudes e habilidades que beneficiarão a eles mesmos e à empresa. (CHIAVENATO, 2009, p. 391)

O processo de treinamento é um ciclo composto por quatro etapas, cíclico e contínuo, como mostrado na figura 1, que garantem o sucesso do programa de treinamento. 


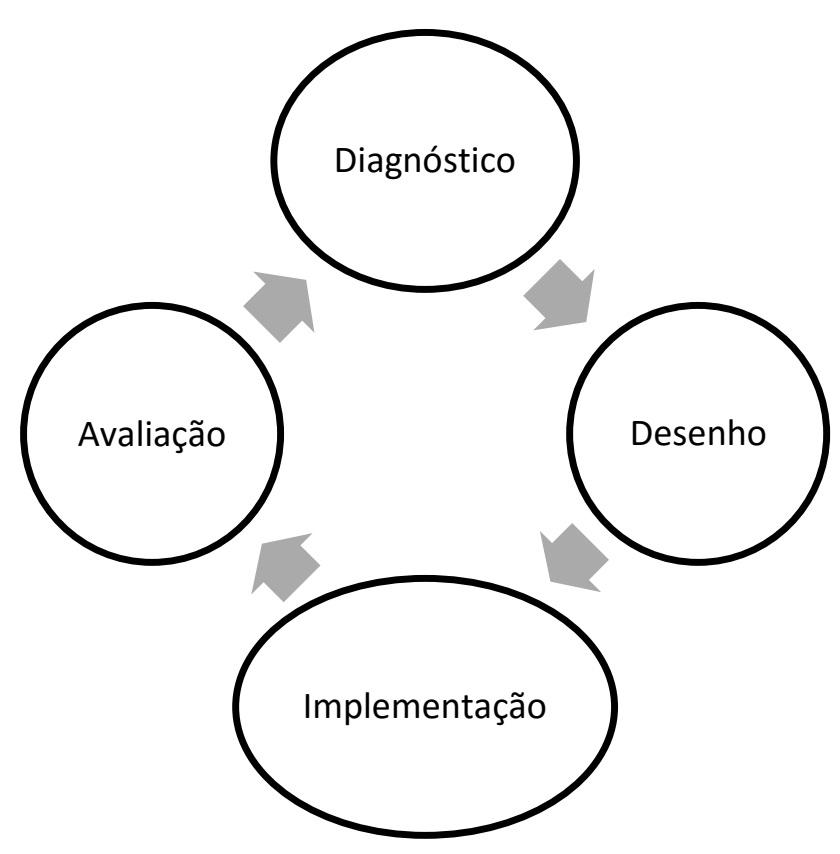

\section{Figura 1: Etapas do treinamento}

Fonte: Chiavenato (2002, p.368)

A etapa do diagnóstico é o levantamento das necessidades ou carências de treinamento a serem atendidas. O desenho é a elaboração do projeto ou programa de treinamento para atender as necessidades levantadas. A etapa de implementação é a execução do programa de treinamento e, por fim, a avaliação é a verificação dos resultados obtidos com o treinamento. (CHIAVENATO, 2002)

O levantamento das necessidades objetiva a identificação de carências, individuais ou grupais, para a realização de uma tarefa. Segundo Gil (2007), esse levantamento se desenvolve em três níveis de análise, que serão explicadas a seguir:

- Organizacional: identificar os níveis de eficiência e eficácia organizacional, a fim de determinar as formas de treinamento que contribuirão para a sua elevação;

- Tarefas: identificar as atividades que compõem as tarefas, assim como os requisitos pessoais necessários para o seu desempenho eficaz;

- Recursos humanos: identificar, junto aos empregados, os níveis de conhecimento, habilidades e atitudes requeridas para a execução das tarefas que praticam.

De acordo com Chiavenato (2002), os principais meios utilizados para o levantamento da necessidade de treinamento são: avaliação de desempenho, 
com a qual é possível descobrir empregados que executam tarefas abaixo do nível satisfatório; observação, verificar onde há evidência de trabalho ineficiente; questionários, pesquisas para evidenciar as necessidades de treinamento; solicitação de supervisores e gerentes; entrevista com supervisores e gerentes, para referenciar problemas solucionáveis através do treinamento; reuniões interdepartamentais; exame de seleção de empregados; modificação do trabalho, para executar a nova tarefa, torna-se necessário o treinamento prévio do empregado; entrevistas de saída; análise de cargos e relatórios periódicos da empresa.

Além dos meios abordados acima, o autor assinala a existência de indicadores que apontam necessidades futuras (a priori) e passadas (a posteriori).

Os indicadores a priori são eventos que, caso aconteçam, favorecerão para que ocorra um treinamento futuro. Esses indicadores são:

- Expansão da empresa e admissão de novos empregados;

- Redução do número de empregados;

- Mudança de métodos e processos de trabalho;

- Substituições ou movimentação de pessoal;

- Faltas, licenças e férias do pessoal;

- Expansão dos serviços;

- Mudanças nos programas de trabalho ou de produção;

- Modernização do maquinário e equipamento;

- Produção e comercialização de novos produtos ou serviços;

Os indicadores a posteriori são os problemas provocados por necessidade de treinamento que não foram atendidas. Esses problemas podem estar relacionados com a produção ou com o pessoal, e expõem necessidades de treinamento.

a) Problemas de produção

- Baixa qualidade de produção;

- Baixa produtividade;

- Avarias (irregularidades) frequentes em equipamentos e instalações;

- Comunicações defeituosas;

- Excesso de erros e desperdícios;

- Elevado número de acidentes no trabalho; 
- Pouca versatilidade dos empregados;

- Mau aproveitamento do espaço disponível.

b) Problemas de Pessoal

- Relações deficientes entre o pessoal;

- Número excessivo de queixas;

- Mau atendimento ao cliente;

- Comunicações deficientes;

- Pouco interesse pelo trabalho;

- Falta de cooperação;

- Erros na execução de ordens

Dias (2012 apud Oliveira, 2006) aborda que o modelo de treinamento e desenvolvimento (T\&D) vem apresentando sinais de esgotamento. A antiga forma de se realizar T\&D entrou em declínio, pois não está sendo mais útil. Até a própria expressão T\&D envelheceu e já pede uma substituta. Essa substituta é a educação corporativa (EC), que, segundo a autora, é uma evolução do antigo modelo de treinamento e desenvolvimento.

Chiavenato (2009) corrobora o pensamento de Dias (2012) ao afirmar que as organizações caminham gradativamente do treinamento e desenvolvimento para a educação corporativa, em migração paulatina e definitiva. A diferença entre esses conceitos é que a T\&D é quase sempre local, tópico, reativo, microorientado e agregador. Já a educação corporativa é vantajosa por ser holística, sistêmica, proativa e sinérgica.

Pereira (2004) afirma que a Universidade Corporativa (UC) é o modelo de uso mais comum na aplicação do conceito de educação corporativa. É um processo centralizado de educação com relevância estratégia para as competências essenciais de uma organização.

\subsection{Universidade Corporativa}

\subsubsection{Histórico}

O treinamento e desenvolvimento evoluiu de uma abordagem mecanicista e operacional, para uma abordagem holística e sistêmica, com uma atuação voltada para o desenvolvimento e o sucesso do negócio; isso se deve ao fato da 
mudança da Era Industrial para a Era do Conhecimento. Com essa mudança as empresas passaram a integrar os esforços da formação profissional, criando suas próprias escolas e elevando o processo de treinamento a uma atuação estratégica. (PEREIRA, 2004)

Segundo Eboli (2010 apud Meister, 1999), cinco forças sustentaram a mudança de centros de treinamento e desenvolvimento, para Universidades Corporativas; são elas:

- Organizações flexíveis - a emergência da organização não hierárquica, enxuta e flexível, com capacidade de dar respostas mais rápidas ao turbulento ambiente empresarial.

- Era do conhecimento - mudança da era industrial, para a era do conhecimento, no qual o conhecimento é a base para a formação de riquezas nos níveis individual, empresarial ou nacional.

- Rápida obsolescência do conhecimento - com o avanço cada vez mais rápido da ciência e da tecnologia, o conhecimento tem tido rápida circulação e se renovado constantemente. A necessidade de adquirir e renovar o conhecimento está presente nas organizações e nas pessoas.

- Empregabilidade - um novo foco com relação à empregabilidade; mais voltada para a capacidade de estar em uma ocupação do que estar em um emprego a vida toda.

- Educação para a estratégia global - necessidade de formar pessoas com visão global e perspectivas internacionais do mundo. A aprendizagem e o trabalho caminham juntos.

Neste novo contexto empresarial surge a preocupação com a gestão de pessoas por competências, e não mais por cargo, como antigamente era praticado pelas empresas. (EBOLI, 2010).

A educação corporativa transforma a função de treinamento e desenvolvimento, à medida que se propõe a formular um conceito de atuação projetado à era do conhecimento. Uma nova atuação que reconhece as necessidades de agregar valor aos negócios empresariais. (PEREIRA, 2004).

A universidade corporativa incorpora a filosofia de aprendizagem da organização, que é uma mentalidade com foco em disponibilizar para todos os níveis de empregados os conhecimentos, habilidades e competências 
necessárias para atingir os objetivos estratégicos da organização. (EBOLI, 2010 apud MEISTER, 1999)

No Brasil, a adoção desse conceito começou na década de 90, com advento de um mercado cada vez mais globalizado, pressionando assim as organizações a investirem na qualificação de seus colaboradores e comprometerem-se com seu desenvolvimento contínuo, como um elemento-chave na criação de diferencial competitivo. (EBOLI, 2005, p.92)

Eboli (2010) afirma que o marco do surgimento do tema educação corporativa no Brasil foi o lançamento do livro de Jeanne Meister, em 1999. Segundo a autora, nessa época já existiam casos de universidades corporativas no país, mas ainda eram experiências pontuais, e o conhecimento delas advindo não havia sido codificado e disseminado.

A primeira experiência de implantação registrada foi a da Academia Accor, em 1992. Em seguida, foram divulgadas a Universidade Martins do Varejo (1994), a Universidade Brahma (1995), a Universidade do Hambúrguer, do McDonald's (1997), o Visa Training, criado em 1997, que originou a Universidade Visa, lançada oficialmente em 2001, a Universidade Algar, fundada em 1998, a Alcatel University e o Siemens Management Learning, em 1998, a Boston School do BankBoston e a Universidade Datasul, implantadas em 1999. Com isso, na década de 1990, em torno de 10 empresas haviam constituído suas UCs. (EBOLI, 2010, p. 141)

Segundo Eboli (2010), o conceito de Universidade Corporativa corresponde à implementação dos seguintes aspectos:

- Objetivo principal - desenvolver as competências críticas do negócio em vez de habilidades individuais.

- Foco do aprendizado - privilegiar o aprendizado organizacional, fortalecendo a cultura corporativa e o conhecimento coletivo, e não apenas o conhecimento individual.

- Escopo - concentrar-se nas necessidades dos negócios, tornando o escopo estratégico, e não focado exclusivamente nas necessidades individuais.

- Ênfase dos programas - conceber e desenhar ações e programas educacionais a partir das estratégias de negócios, ou seja, da identificação das competências críticas empresariais.

- Público-alvo - adotar o conceito de educação inclusiva. Desenvolvendo competências críticas no público interno e externo (familiares, clientes, fornecedores, distribuidores, parceiros comerciais e comunidade), e não somente nos funcionários. 
- Local - contemplar a possibilidade de ser um projeto virtual e não necessariamente um local físico.

- Resultado - aumentar a competitividade empresarial e não apenas habilidades individuais.

Eboli (2010) contempla que nas UCs as organizações estão reestruturando os ambientes de aprendizagem para que eles sejam proativos, centralizados, determinados e realmente estratégicos por natureza. "Considere o modelo de universidade corporativa um processo, e não necessariamente um lugar. " (EBOLI, 2010, p. 151 apud Meister, 1999)

Diante do cenário de extrema competitividade, o desenvolvimento de um sistema de educação corporativa, que busque a instalação das competências empresariais e humanas para a viabilização das estratégias de negócio, de forma sistemática, estratégica e contínua, é visto de forma importante na criação de valor real agregado às pessoas envolvidas e ao negócio. (EBOLI, 2004)

A qualidade de um sistema de educação corporativa depende da qualidade de pensamento de seus idealizadores, e da elaboração de um projeto que contenha práticas associadas a cada um dos princípios de sucesso. (EBOLI, 2004)

Segundo Eboli (2010), os sistemas de educação corporativa apresentam sete princípios de sucesso, que são a base para a constituição de um Sistema de Educação Corporativa bem-sucedido. Os princípios são:

- Competitividade - valorizar a educação como meio de desenvolver o capital intelectual dos colaboradores, transformando-os em fator de diferenciação da empresa. Consolidando assim, a sua capacidade de competir e aumentando seu valor de mercado através do aumento do valor das pessoas.

- Perpetuidade - entender a educação como um processo de transmissão da herança cultural, que exerce influência intencional e sistemática com o propósito de formação de um modelo mental, a fim de conservar, transmitir, disseminar, reproduzir ou até mesmo transformar as crenças e valores organizacionais, para perpetuar a existência da empresa.

- Conectividade - Privilegiar a construção social do conhecimento, estabelecendo conexões, intensificando a comunicação da empresa, e favorecendo a inteiração do público interno e externo da organização, que 
gerem, compartilhem e transfiram os conhecimentos organizacionais considerados críticos para o negócio.

- Disponibilidade - oferecer e disponibilizar recursos educacionais, que propiciem condições para o processo de aprendizagem a qualquer hora e em qualquer lugar, estimulando-os a se responsabilizarem pelo processo de aprendizagem contínua e autodesenvolvimento.

- Cidadania - Estimular o exercício da cidadania individual e corporativa e da construção social do conhecimento organizacional.

- Parceria - Desenvolver continuamente as competências críticas dos colaboradores, exigindo que se estabeleçam relações de parceria no âmbito interno e externo.

- Parceria Interna - parceria com líderes e gestores, a fim de que se responsabilizem pela educação e aprendizagem de suas equipes e que desempenhem o papel de educador, formador e orientador no cotidiano de trabalho.

- Parceria Externa - parceria com universidades, instituições de nível superior, ou até mesmo fornecedores, que agreguem valor ao negócio. Essas alternativas diminuem a vulnerabilidade do projeto de educação corporativa, e viabilizam que a educação seja contínua, permanente e estratégica.

- Sustentabilidade - Centro gerador de resultados para a empresa, buscando agregar sempre valor ao negócio. Significa também buscar fontes alternativas de recursos que permitam um orçamento próprio e autossustentável.

Dias \& Guedes (2013) afirmam que no princípio Sustentabilidade, são evidenciadas práticas que possibilitam o suporte ao sistema de educação corporativa. Uma dessas práticas é a implantação de um sistema métrico para avaliar seus resultados.

\subsection{Avaliação em educação corporativa}

A necessidade de mostrar o valor das ações de educação corporativa, seja para manter sua sobrevivência, seja para ganhar mais espaço e verbas na organização, fez com que muitos departamentos responsáveis pelos programas 
de treinamento investissem em modelos de mensuração e avaliação de ações educacionais. (PALMEIRA, 2012).

Junior (2010) complementa a utilidade da avaliação dos programas educacionais ao afirmar que um dos seus principais objetivos é o de trazer melhores resultados para a organização. Isso só reforça a importância de descobrir os resultados provenientes desses programas.

A avaliação em uma educação corporativa deve estar alinhada à avaliação de desempenho da organização; já que a educação corporativa promove ações educacionais ligadas à estratégia organizacional e preza a gestão do conhecimento organizacional. (JUNIOR, DIAS, EBOLI, 2013)

"A avaliação contínua dos programas de educação corporativa e a demonstração de seus impactos podem levar à aprovação de novas edições e outros programas, permitindo também a melhoria dos existentes." (PALMEIRA, 2012, p.235).

Junior (2010 apud Kirkpatrick,1998) afirma que um programa educacional é bem-sucedido quando os participantes selecionados recebem conhecimento, habilidades e atitudes ensinadas por métodos, meios e instrutores adequados, de tal forma que atendam ou superem as expectativas da organização.

A avaliação das ações de educação corporativa pode utilizar uma combinação de metodologias para avaliação de treinamentos, dentre os diversos métodos existentes. (PALMEIRA, 2012)

Donald Kirkpatrick foi um dos pioneiros a propor uma metodologia estruturada para avaliação de treinamento. (JUNIOR, 2010; MARINELLI, 2007). Essa metodologia avalia o treinamento em quatro níveis: reação, aprendizagem, comportamento e resultados. Reação é o nível que mensura a satisfação do empregado frente ao treinamento realizado, aprendizagem verifica o quanto foi adquirido de conhecimento pelo participante, o terceiro nível identifica a mudança do comportamento do treinado e, por último, a verificação dos resultados no negócio organizacional.

Hamblin modificou esse método, ao desdobrar o quarto nível (resultados) em dois, e propôs cinco níveis de avaliação de treinamento: reação, aprendizagem, comportamento no cargo, mudança organizacional e valor final, positivamente relacionados entre si. (MARINELLI, 2007 apud HAMBLIN, 1978)

Um modelo de avaliação deve ser claro e simples; produzir o mesmo resultado a cada vez que for aplicado à mesma situação ou treinandos; 
oportuno; e adequado ao que se pretende medir. (MARINELLI, 2007 apud SILVA, 1983)

$\mathrm{Na}$ tabela a seguir, Marinelli (2007) comparou outras metodologias, com foco na avaliação de programas de treinamento, à de Kirkpatrick.

Tabela 1: Comparação entre as principais metodologias

\begin{tabular}{|cccccc|}
\hline $\begin{array}{c}\text { Metodologia } \\
\text { Kirkpatrick } \\
(\mathbf{1 9 5 9 )}\end{array}$ & Nível 1 & Nível 2 & Nível 3 & Nível 4 & Nível 5 \\
\hline $\begin{array}{c}\text { Hamblin } \\
\text { (1978) }\end{array}$ & Reação & Aprendizagem & Comportamento & Resultados & - \\
\hline $\begin{array}{c}\text { Borges- } \\
\text { Andrade } \\
\text { (1982) }\end{array}$ & $\begin{array}{c}\text { Insumos, } \\
\text { procedimentos } \\
\text { e processos }\end{array}$ & Resultados & $\begin{array}{c}\text { Comportamento } \\
\text { no cargo }\end{array}$ & $\begin{array}{c}\text { Mudança } \\
\text { organizacional }\end{array}$ & Valor Final \\
\hline $\begin{array}{c}\text { (resultados a } \\
\text { longo prazo) } \\
(\mathbf{1 9 9 6 )}\end{array}$ & Reação & Aprendizagem & $\begin{array}{c}\text { Comportamento } \\
\text { (resultados a } \\
\text { longo prazo) }\end{array}$ & $\begin{array}{c}\text { Ambiente } \\
\text { (resultados } \\
\text { a longo } \\
\text { prazo) }\end{array}$ \\
\hline
\end{tabular}

Fonte: adaptado de Marinelli (2007, p. 180)

De acordo com Marinelli (2007), há uma grande semelhança entre as metodologias em termos de estrutura; as diferenças são, principalmente, em relação às nomenclaturas utilizadas. Essa semelhança também está presente na base da definição dessas metodologias, que se fundamentam em Kirkpatrick e Hamblin.

"Tal posição é corroborada por Abbad, Pilati e Pantoja (2003), que, por meio de um levantamento da literatura, apontam a falta de uma visão mais abrangente na proposta de novos modelos." (JUNIOR, DIAS, EBOLI, 2013, p. 5)

Uma divergência que pode ser notada entre os modelos é que o nível Resultados para Kirkpatrick é qualquer mudança que tenha no mundo organizacional e, que provenha do treinamento. Já Phillips separa essa resultante em: resultados organizacionais e valor financeiro (retorno sobre o investimento).

A definição de valor final, no modelo de Hamblin, se assemelha ao do ROI de Phillips, que é a comparação dos custos do treinamento com seus benefícios. A divergência entre as metodologias é que o ROI sempre busca quantificar financeiramente, já no valor final se aceita que o resultado não seja quantificado. 
O modelo de Borges-Andrade é o primeiro modelo a abordar o ambiente na avaliação. Os resultados a longo prazo, que são subcomponentes do ambiente, equivalem aos níveis 3 a 5 de Hamblin.

Nos tópicos a seguir serão descritos alguns dos modelos de avaliação de treinamento. Optou-se por apresentar apenas o modelo de Kirkpatrick, de forma detalhada, pois é referência no campo teórico e, normalmente, é aplicado nas organizações.

\subsubsection{Modelos de Avaliação de Treinamento}

\subsubsection{Modelo de Kirkpatrick}

"O propósito de se avaliar um programa de treinamento é determinar sua eficácia." (KIRKPATRICK; KIRKPATRICK, 2010, p.21). Ainda segundo o autor, existem três motivos para que se avalie um programa de treinamento: justificar a existência e a verba do departamento de treinamento, demonstrando que ele contribui para as metas e os objetivos da empresa; para decidir entre continuar e desativar programas de treinamento e; para obter informações sobre como melhorar programas de treinamento futuros.

Segundo Kirkpatrick (2010), a avaliação de treinamento deve seguir quatro níveis sequenciais. Cada nível é importante e impacta sobre o nível seguinte. De acordo com o autor, com o passar de nível, as informações obtidas são mais valiosas. Contudo, o processo se torna mais difícil e demorado. Os quatro níveis serão detalhados a seguir.

O nível 1, é o da reação, onde se mensura a reação dos participantes frente ao programa de treinamento, apurando assim a sua satisfação. A avaliação pode ser feita a partir de um questionário para medir as impressões dos participantes sobre os treinamentos, abordando o programa, o conteúdo, instrutores, recursos, ambiente e instalações. De acordo com o autor, todos os programas deveriam ser avaliados nesse nível, como forma de promover melhorias.

Esse é o nível mais avaliado pelas organizações, muitas vezes é conceituado como pesquisa de opinião dos participantes. O resultado dessa avaliação pode servir como base para decisões relativas ao programa, como a continuidade, mantendo pontos fortes, incorporando itens sugeridos para melhoria, a extinção ou o desdobramento em mais cursos. Os formulários de 
reação também fornecem informações quantitativas que podem ser usadas para definir padrões de desempenho para os próximos programas a serem implantados. (KIRKPATRICK; KIRKPATRICK, 2010; MARINELLI, 2007; PALMEIRA, 2012)

Outra razão para realizar essa medição é a certificação do interesse e da motivação dos participantes. Caso a reação seja negativa, é provável que não se sintam motivados a aprender. "Uma reação positiva não garante o aprendizado, porém é quase certo que uma reação negativa reduz a possibilidade de ele ocorrer." (KIRKPATRICK; KIRKPATRICK, 2010, p.38)

No nível 2, aprendizagem, a avaliação ocorre por meio da verificação da mudança da atitude, aumento de conhecimento ou habilidade do participante em decorrência do treinamento. Segundo Kirkpatrick (2010), somente com a identificação de um desses resultados, se define que ocorreu o aprendizado. A mensuração pode ocorrer através de testes individuais ou em equipe.

Alguns treinamentos pretendem aprimorar o conhecimento de conceitos, princípios e técnicas dos empregados. Outros pretendem ensinar novas habilidades e aprimorar as antigas. E algumas tentam mudar atitudes. (MARINELLI, 2007 apud KIRKPATRICK, 1998b)

"Uma avaliação do aprendizado pode ser construída dentro do treinamento, estabelecendo-se situações anteriores e posteriores nas quais os participantes demonstram se aprenderam os princípios e técnicas ensinados." (MARINELLI, 2007, p.131). Sendo assim, uma comparação das avaliações aplicadas, antes e depois do programa, pode identificar a diferença do aprendizado.

Kirkpatrick (2010) aborda que ao avaliar o aprendizado dos alunos, também se está avaliando a competência dos instrutores. O resultado dessa avaliação pode culminar em soluções, dadas pelos próprios participantes, para se obter a melhoria do aprendizado, como a mudança da abordagem, utilização de recursos que ajudem a comunicar de maneira mais eficaz e até a substituição do instrutor.

O objetivo do nível 3, comportamento, é identificar a mudança de comportamento do colaborador, em virtude da participação no programa de treinamento.

De acordo com Kirkpatrick (2010), para que a mudança ocorra são necessárias quatro condições: a pessoa precisa querer mudar; saber o que fazer 
e como fazê-lo; trabalhar no ambiente adequado e; precisa ser recompensada pela mudança.

Os dois primeiros requisitos podem ser atendidos a partir da participação no programa de treinamento. $\mathrm{Na}$ terceira condição, o ambiente pode ser de coibição, desestímulo, neutralidade, apoio e exigência. $O$ tipo de ambiente está relacionado ao superior imediato do participante. (KIRKPATRICK; KIRKPATRICK, 2010)

Um ambiente de coibição é quando o chefe proíbe o participante de pôr em prática o que foi ensinado. Isso pode ser originado por uma cultura organizacional implantada pela diretoria.

Em um ambiente de desestímulo não há proibição de mudança no comportamento, mas o superior deixa claro que ficará descontente caso isso ocorra.

Neutralidade é quando o chefe ignora o fato do subordinado ter passado por um programa de treinamento, tudo continua como antes. Se o subordinado quiser mudar, não haverá objeção, desde que o trabalho seja feito. Contudo, se houver resultados negativos, o chefe poderá criar um ambiente de desestímulo ou coibição.

Em um ambiente de apoio há o encorajamento para aprender e aplicar no trabalho o aprendizado. $O$ ideal era que o superior conversasse sobre 0 programa de treinamento, antes de seu início, e combinasse como poderia aplicá-lo, assim que o programa tiver terminado.

Exigência é um ambiente em que o chefe sabe o que foi aprendido e assegura que o aprendizado seja aplicado no trabalho. Em alguns casos, é feito um contrato de aprendizagem, comprometendo o empregado a pôr em pratica tudo o que aprendeu.

A quarta condição, recompensa, pode ser intrínseca - que inclui as sensações de satisfação, orgulho e realização - e extrínseca - que inclui elogios, reconhecimento e recompensas monetárias -, ou ambas. (KIRKPATRICK; KIRKPATRICK, 2010)

Em um ambiente de cobiça ou desestímulo, a probabilidade de gerar uma mudança de comportamento, é bem pequena. Já em um ambiente de neutralidade, a mudança depende das outras três condições ditas anteriormente (querer mudar, saber o que fazer e como fazer e a recompensa pela mudança). Se o ambiente for de apoio ou exigência, o grau de mudança irá ocorrer de acordo com a primeira e a segunda condições. 
É importante os instrutores saberem o tipo de ambiente que os
participantes irão enfrentar ao voltarem do programa de
treinamento. Também é importante que eles façam todo o
possível para que o ambiente seja neutro ou melhor que isso,
caso contrário, a probabilidade de o programa gerar mudança
de comportamento e cumprir os objetivos esperados será
pouca ou nenhuma, pois os participantes nem tentarão aplicar
o que aprenderam. (...). Um modo de criar um ambiente
positivo no trabalho é envolver os chefes no desenvolvimento
do programa. (KIRKPATRICK; KIRKPATRICK, 2010, p. 40)
ado, verifica como o treinamento afetou positivamente os

O nível 4, resultado, verifica como o treinamento afetou positivamente os resultados do negócio. "Os resultados finais podem incluir aumento da produção, melhora da qualidade, redução de custos, menor frequência e/ou gravidade de acidentes, mais vendas, menor rotatividade e lucros mais altos.". (KIRKPATRICK; KIRKPATRICK, 2010, p. 41)

Kirkpatrick (2010) aborda que há resultados que não podem ser mensurados de forma monetária, como liderança, motivação, administração do tempo, tomada de decisão ou gestão de mudanças.

Uma das críticas a esse modelo, além de não medir o retorno do investimento, é que é muito mais fácil ver as evidencias do que obter provas.

Quando olhamos para a avaliação de reação, aprendizagem, comportamento, e resultados, podemos ver que a evidência é muito mais fácil de se obter do que a prova. Em alguns casos, a prova é pouco prática e quase impossível de se conseguir. (MARINELLIS 2007, apud Kirkpatrick, 1998, p.79)

Essas provas são difíceis de obter, pois é difícil afirmar que apenas o treinamento foi o responsável pelo efeito de incremento de um resultado na organização. Essa afirmação só poderia ser feita se as condições de ambiente ou mercado fossem mantidas.

Em relação à quantificação dos resultados provenientes dos programas de treinamento, Jack Phillips, cujo modelo será apresentado na sequência, foi além da metodologia de Kirkpatrick. (PALMEIRA, 2012)

\subsubsection{Modelo de Phillips}

O retorno sobre o investimento (em inglês return on investment - ROI) é uma das maneiras que possibilitam a comprovação da eficácia dos programas de educação corporativa. A maioria dos profissionais reconhece a necessidade de assegurar um retorno dos investimentos em educação corporativa, isso possibilita a manutenção dos orçamentos de educação corporativa, 
principalmente em situações de crise, e o aumento do status da área de recursos humanos. (MARINELLI, 2007 apud PHILLIPS, 1998b)

Assim como Kirkpatrick (2010), Phillips (2007) utiliza o nível 1 como reação, o 2 como aprendizagem e o 3 como mudança de atitude. O que diferencia, assim como Hamblin (1978), é o desdobramento do quarto nível, que para Kirkpatrick são os resultados, em resultados profissionais e ROI.

Em sua metodologia, Phillips chama o nível 1 de reação,
satisfação e ação planejada, inserindo um plano de ação para
estimular resultados futuros nesse nível. Mantém o nível 2
como aprendizagem e destaca a aplicabilidade e e
implementação no nível 3 , transformando o nível 4 em
resultados profissionais, quando então adiciona um quinto nível
relacionado ao ROI, que compara os benefícios do programa
aos seus custos, mostrando o valor que ele agregou (se
houver). (PALMEIRA, 2012, p. 237)

Phillips (2007) aborda que para que seja conduzida a avaliação do nível cinco, torna-se necessário responder às seguintes questões:

- Nível um - Reação e ação planejada: Qual a reação dos participantes em relação ao programa? O que eles planejam fazer com que aprenderam?

- Nível dois - Aprendizagem: Que habilidades, conhecimento ou atitudes tem mudado? Quanto têm mudado?

- Nível três - Aprendizagem aplicada no trabalho: Os participantes aplicam o que eles aprenderam no trabalho?

- Nível quatro - Resultados profissionais: A aplicação no trabalho produz resultados mensuráveis?

- Nível cinco - Retorno do investimento: Os valores monetários dos resultados excederam o custo do programa?

De acordo com Phillips (2007), os benefícios de utilizar o ROI são para mostrar as contribuições dos programas de treinamento, justificar os orçamentos disponibilizados, identificar programas ineficientes que precisam ser reestruturados ou eliminados, alinhar o aprendizado às necessidades de negócios, melhorar o apoio aos programas, ganhar respeito da alta gerência e identificar programas bem sucedidos que podem ser implementados em outras áreas.

Muitas organizações conduzem avaliações para medir a satisfação, contudo, poucas conduzem avaliações no nível do ROI. "Ambas as categorias de avaliação são desejáveis. É evidente que se as medições não são tomadas em 
cada nível, fica difícil demonstrar que qualquer progresso pode ser atribuído ao treinamento." (MARINELLI, 2007, p. 138)

Os dados das medições realizadas em cada nível são convertidos em valores monetários, chamados de benefícios na fórmula a seguir. Alguns dados são facilmente convertidos em valores/unidades monetárias, como redução de desperdício, horas de treinamento e unidades adicionais vendidas. Já para outros, como satisfação no trabalho, lealdade dos funcionários, essa conversão não é trivial. Para esses casos, Philips sugere algumas estratégias que fornecem resultados financeiros em diferentes níveis de confiabilidade: custos históricos (se mantidos pela organização); opinião de especialistas (internos ou externos que conheçam o negócio); estudos externos; estimativas dos participantes, gerentes ou dos profissionais de Recursos Humanos. (PALMEIRA, 2012)

A partir da conversão dos dados e do cálculo dos custos, o ROI será calculado pela seguinte fórmula:

$$
R O I=\frac{\text { Benefícios líquidos }(\text { benefícios }- \text { custo })}{\text { Custos }} \times 100
$$

Fonte: Palmeira (2012 apud Philips, 2003)

Os dados que não possibilitam conversão, como melhorias no relacionamento e melhoria na cooperação, são considerados benefícios intangíveis. De acordo com Palmeira (2012), para observação dos efeitos do treinamento, Phillips sugere o prazo de até um ano, pois a observação nos anos seguintes, concomitante a outras iniciativas, é mais difícil.

Diferente de Phillips, Hamblin implementa mais um nível na avaliação de Kirkpatrick, buscando avaliar a eficácia do treinamento, que não necessariamente busca obter valores financeiros para o mesmo.

\subsubsection{Modelo de Hamblin}

Hamblin adaptou o modelo de Kirkpatrick desdobrando o quarto nível em dois. Dessa forma, os três primeiros níveis são similares ao de Kirkpatrick e os níveis quatro e cinco serão descritos a seguir:

O quarto nível de Hamblin aborda a mudança organizacional, que identifica as mudanças que ocorreram no funcionamento da organização, em decorrência do treinamento realizado. Já o quinto nível, valor final, avalia a eficácia e 
sucesso do programa ministrado, o que implica comparar custos do treinamento com seus benefícios. Contudo, nesse último nível, os valores da avaliação podem ou não ser traduzidos em termos financeiros. (DIAS, GUEDES, 2013; MARINELLI, 2007)

Hamblin afirma que outras variáveis seriam agregadas aos níveis de avaliação, interferindo assim na detecção dos efeitos produzidos pelo treinamento. Dessa forma, a avaliação deveria consistir em coletar os dados relativos aos efeitos nos diferentes níveis e compará-los com os resultados esperados, como apresentado na figura abaixo. (MARINELLI, 2007)

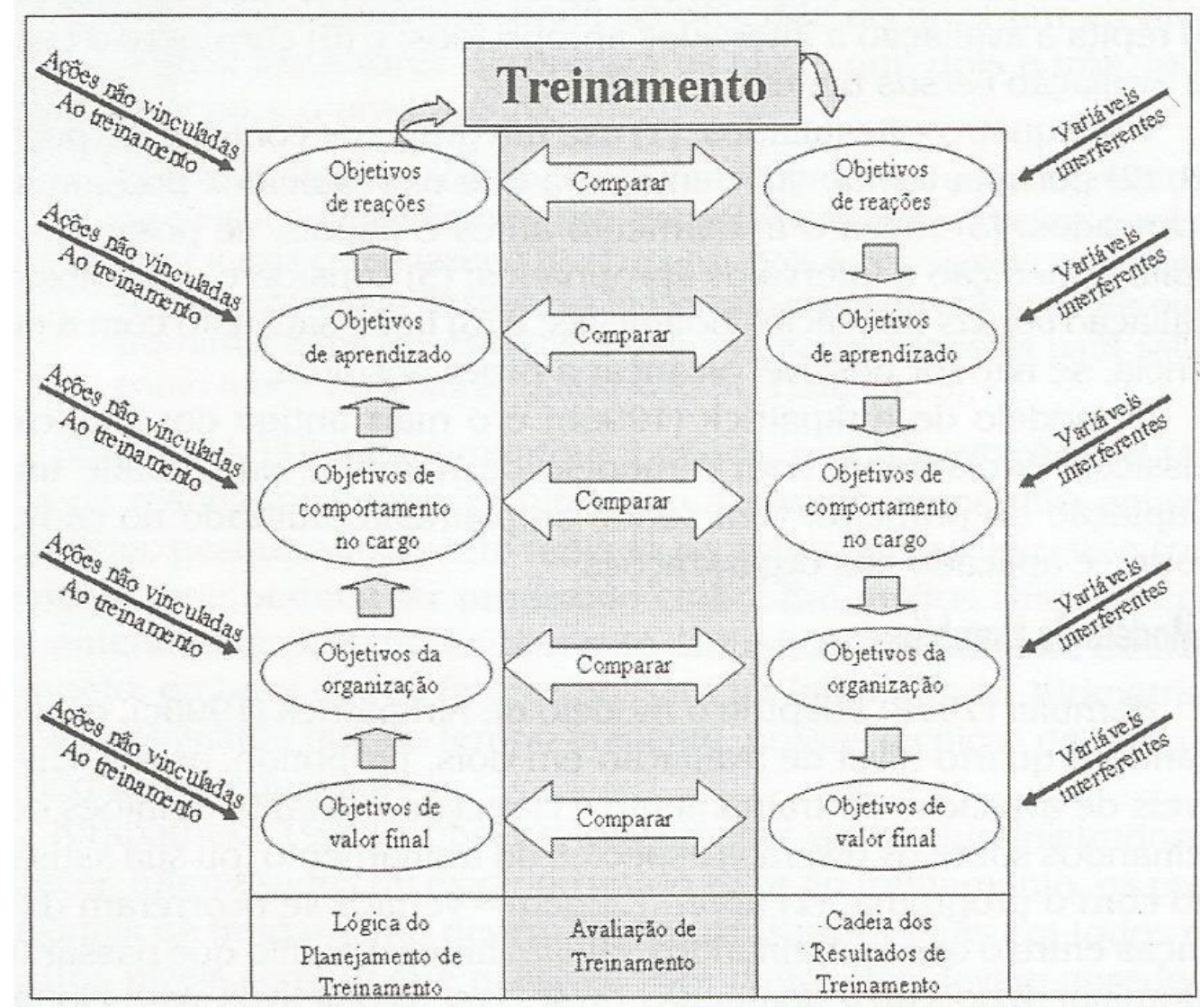

Figura 2: Modelo de Hamblin

Fonte: Marinelli (2007, p. 134)

Hamblin, em sua metodologia, menciona que ao planejar o treinamento é importante também planejar os possíveis resultados que cada nível pode oferecer. Além disso, ele aborda a interferência de fatores externos ao do treinamento, que podem influenciar nos resultados das avaliações. Os próximos autores a serem apresentados corroboram esses pensamentos. Palmeira (2012), 
em seu método, cria um nível anterior ao da reação, que determina a meta esperada para o programa de treinamento a ser oferecido. Borges-Andrade (2002) incorpora, em sua metodologia, os níveis externos para a realização da avaliação.

\subsubsection{Modelo de Palmeira}

O modelo de Palmeira adiciona o nível 0 , chamado de embasamento estratégico, anterior ao nível 1 de Kirkpatrick (2010). Mantém-se o nível 2 e; segundo a autora, adaptando à realidade brasileira, agrupam-se os níveis 3 a 5 das escalas de Kirkpatrick e Phillips em um único nível 3, chamado de impacto. (PALMEIRA, 2012)

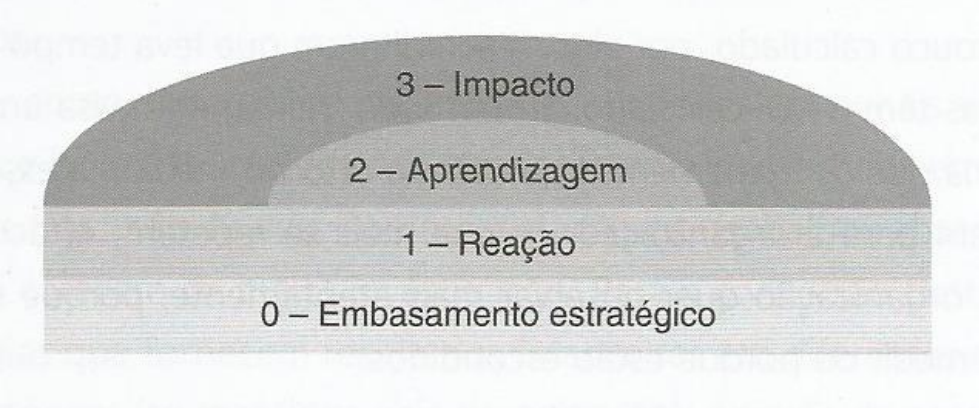

\section{Figura 3: Modelo de Palmeira}

Fonte: Palmeira (2012, p. 240)

O embasamento estratégico ocorre no planejamento de um novo programa de treinamento ou capacitação, ou na revisão do mesmo. "Ou seja, antes de desenvolver um novo programa (...), a primeira coisa a ser feita é verificar a qual meta organizacional ele irá suportar”. (PALMEIRA, 2012, p. 240)

Dessa forma, a justificativa para a participação de um funcionário em um programa de treinamento deve contribuir para uma meta individual, que contribuirá para uma meta organizacional, para que assim se atinja os resultados almejados. (PALMEIRA, 2012)

\subsubsection{Modelo de Borges-Andrade}

O modelo de avaliação integrado e somativo (MAIS) foi desenvolvido por Borges-Andrade em 1982, e é o modelo pioneiro brasileiro de avaliação de 
treinamento (MARINELLI, 2007). De acordo com Borges-Andrade (2002) esse modelo privilegia os aspectos instrucionais e administrativos que geralmente produzem reações nos participantes dos treinamentos. Ele é constituído de cinco componentes: insumos, procedimentos, processos, resultados e ambiente. $O$ último componente, ambiente, é o maior e permeia os demais elementos, além disso, ele é subdividido em quatro dimensões, que são: necessidade, suporte (apoio), disseminação e efeitos em longo prazo. (BORGES-ANDRADE, 2002)

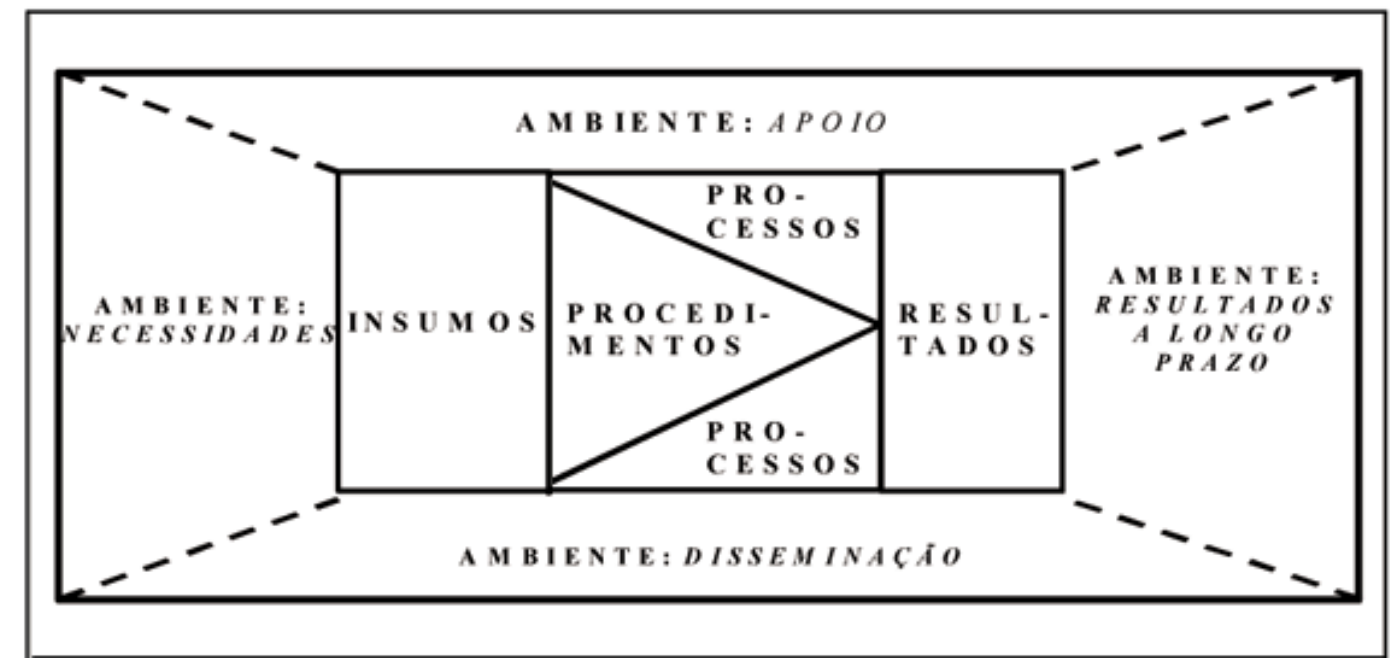

Figura 4: Modelo MAIS de Borges-Andrade

Fonte: Borges-Andrade (2002, p. 34)

Os insumos correspondem a fatores físicos e sociais e estados comportamentais, que precedem ao treinamento e que podem afetar sua realização. Procedimentos são operações realizadas para conduzir os resultados instrucionais, controladas pelo instrutor ou algum meio de entrega de instrução. Processos referem-se a reações comportamentais do participante em relação ao procedimento utilizado, normalmente estão associadas a desempenho intermediários dos treinandos. Resultados tratam do que foi aprendido e o que foi alcançado, pelos treinandos, ao final do treinamento. (BORGES-ANDRADE, 2002)

O ambiente é dividido em quatro subcomponentes: necessidades, apoio, disseminação e resultados a longo prazo.

As necessidades são definidas como discrepâncias entre os desempenhos esperados e os apresentados, podendo influenciar nos insumos. O apoio é o elemento relacionado à infraestrutura ou procedimentos e processos que influenciam na aprendizagem. Esse subcomponente influencia diretamente os 
insumos, procedimentos e processos, e indiretamente a aprendizagem e os resultados a longo prazo. A disseminação inclui os meios e as estratégias para a divulgação das ações de treinamentos. Já os resultados são as consequências ambientais do treinamento medidas a longo prazo; nele estão inseridos os níveis três a cinco propostos por Hamblin (1978). (BORGES-ANDRADE, 2002)

O modelo de Borges-Andrade contempla variáveis externas a do treinamento no momento da avaliação. Contudo, ele avalia o programa de treinamento e as variáveis que o influenciam, mas não avalia a organização de forma abrangente e ampla. Esse tipo de avaliação é abordado no Modelo de Produtividade de Allen e McGee.

\subsubsection{Modelo de Allen e McGee}

O Modelo de Produtividade de Allen e McGee (2004) propõe métricas organizacionais de efetividade da universidade corporativa. Os autores destacam que o objetivo é mensurar a organização, por isso métricas organizacionais, como satisfação e retenção de funcionários, crescimento, lucratividade e produtividade, são mais apropriadas para medir o sucesso. (JUNIOR, DIAS, EBOLI, 2013)

Allen e McGee (2004) abordam que o modelo de Kirkpatrick, com os quatro níveis, e o de Phillips, com a medição do ROI, são boas ferramentas para medir programas individuais. Contudo, o modelo de produtividade proposto por esses autores, defende uma abordagem holística, avaliando a educação corporativa em sua totalidade.

"Nem o modelo de Kirkpatrick, nem a fórmula ROI de Phillips fornecem informações que os líderes das universidades corporativas precisam, para melhorar a produtividade do ensino e das atividades correlatas". (ALLEN \& MCGEE, 2004, p. 88). Como modelo alternativo, os autores Allen e McGee (2004) criaram o Modelo de Produtividade, apresentado na figura 5.

A produtividade é alcançada quando há um equilíbrio entre recursos e atividade, e entre atividades e resultados. Isso é demonstrado através das dimensões eficácia e eficiência; essas dimensões serão explicadas a seguir:

- Eficácia: um sistema só é eficaz quando uma atividade cria ou produz um resultado previamente determinado com alto grau de previsibilidade. Eficácia se preocupa com a qualidade do ensino ou desenvolvimento curricular. (ALLEN E MCGEE, 2004; DIAS, GUEDES, 2013) 
- Eficiência: É a relação que existe entre recursos e uma atividade e está condicionada à pergunta "quanto custa". Ela trata da estratégia instrucional e dos recursos envolvidos. Allen e McGee (2004) ressaltam que é importante se preocupar com os recursos e os custos decorrentes das atividades. No entanto, deve-se estar alerta para que as reduções de custos ou recursos não prejudiquem os resultados, ou como definido pelos autores, para que não sejam produzidos resultados "pobres". (ALLEN E MCGEE, 2004; DIAS, GUEDES, 2013)

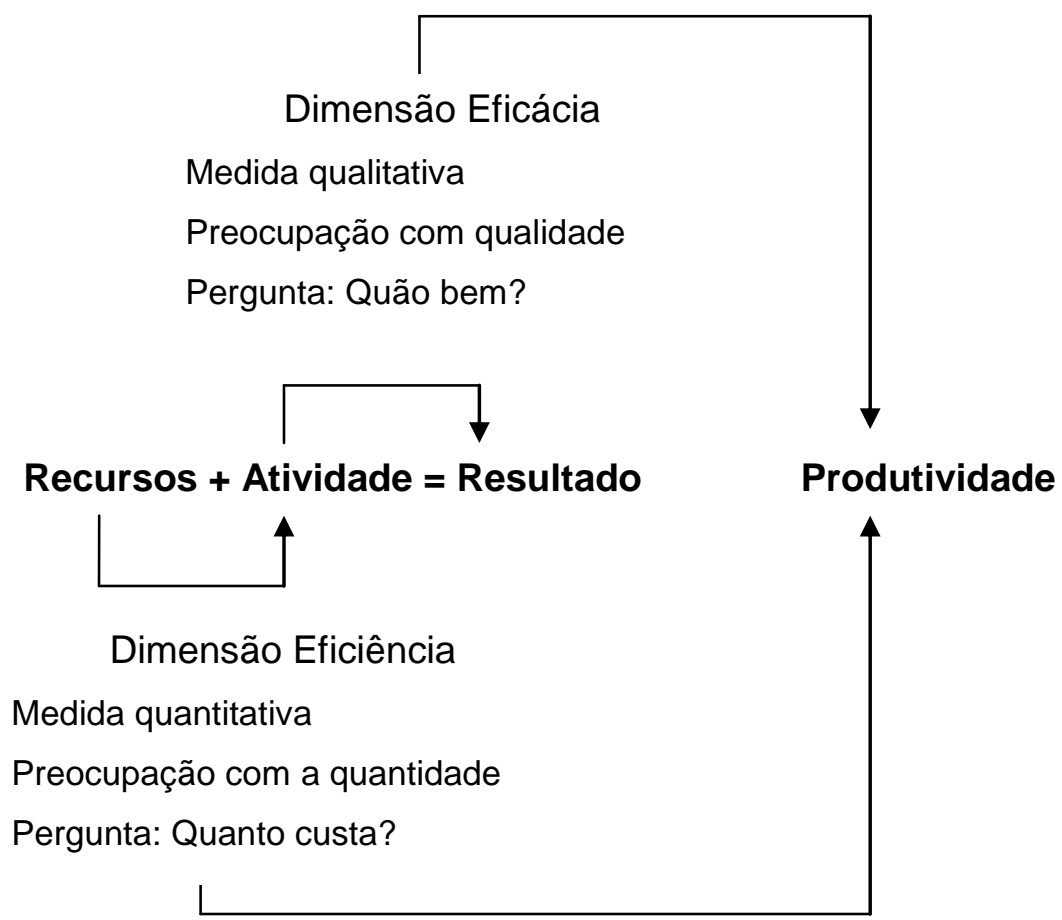

Figura 5: Modelo de Produtividade - Allen e McGee

Fonte: Adaptado de Allen e McGee (2004, p.89)

Diante de todo o exposto, um sistema só será produtivo, se for eficaz e eficiente, simultaneamente.

O Modelo de Produtividade complementa aos quatro níveis de Kirkpatrick, pois busca avaliar a universidade corporativa em sua totalidade, não somente os programas de treinamento de forma individuais. Desse modo, esse modelo pode ser aplicado juntamente ao de Kirkpatrick e com a avaliação do ROI de Phillips. 
“(...) o modelo de produtividade parece estar mais alinhado a uma gestão de natureza mais estratégica e sistêmica com foco restrito à operação das atividades de treinamento, desenvolvimento e educação na organização." (JUNIOR, DIAS, EBOLI, 2013, p. 6)

A verificação de que as ações de uma educação corporativa estão alinhadas ao planejamento estratégico da empresa, pode ser efetuada através da medição de indicadores previamente elaborados.

\subsection{Indicadores}

Medir é primordial para determinar aonde se quer chegar, estabelecer parâmetros, entender expectativas, determinar e mobilizar recursos e reconhecer e recompensar esforços. As organizações necessitam utilizar indicadores, de modo sistêmico, de modo a compor um conjunto de dados que aborde os aspectos importantes da gestão dos negócios. A partir do planejamento estratégico, definem-se as metas e os objetivos esperados para cada departamento. (ASSIS, 2009)

"Os indicadores nasceram da necessidade de manter controle sobre coisas e pessoas" (ASSIS, 2009, p. 15 apud GATASS FILHO, 1998). Através dos indicadores é possível medir o próprio desempenho, comparar resultados, buscando identificar pontos de melhorias e empreender ações de transformação, gerando assim um ciclo de busca das melhores práticas, como apresentado na figura 6. (ASSIS, 2009 apud POMI, 2001)

Esse ciclo é capaz de gerar mudanças significativas, identificar inovações tecnológicas e desenvolver pessoas. Dessa forma, faz-se importante adotar uma dinâmica que permita a melhoria contínua dos processos, produtos e serviços. (ASSIS, 2009)

Os indicadores podem ser usados na esfera individual, por exemplo, para a elaboração de um plano de desenvolvimento pessoal, ou para medir o desempenho obtido durante 0 ano. Eles também podem ser quantitativos, quando se busca dados numéricos, como o cálculo de turnover, absenteísmo e custo de treinamento; ou qualitativos, quando se quer conhecer as opiniões, valores e reações, como a medição da satisfação dos empregados ou clientes. (ASSIS, 2009)

Segundo Assis (2009), é possível ter indicadores que meçam a eficiência e a eficácia dos processos de uma organização. O autor explica o termo eficiência, 
como o consumo dos recursos utilizados para a obtenção dos resultados; já a eficácia é o alcance do propósito de determinada ação, ou conjunto de ações.

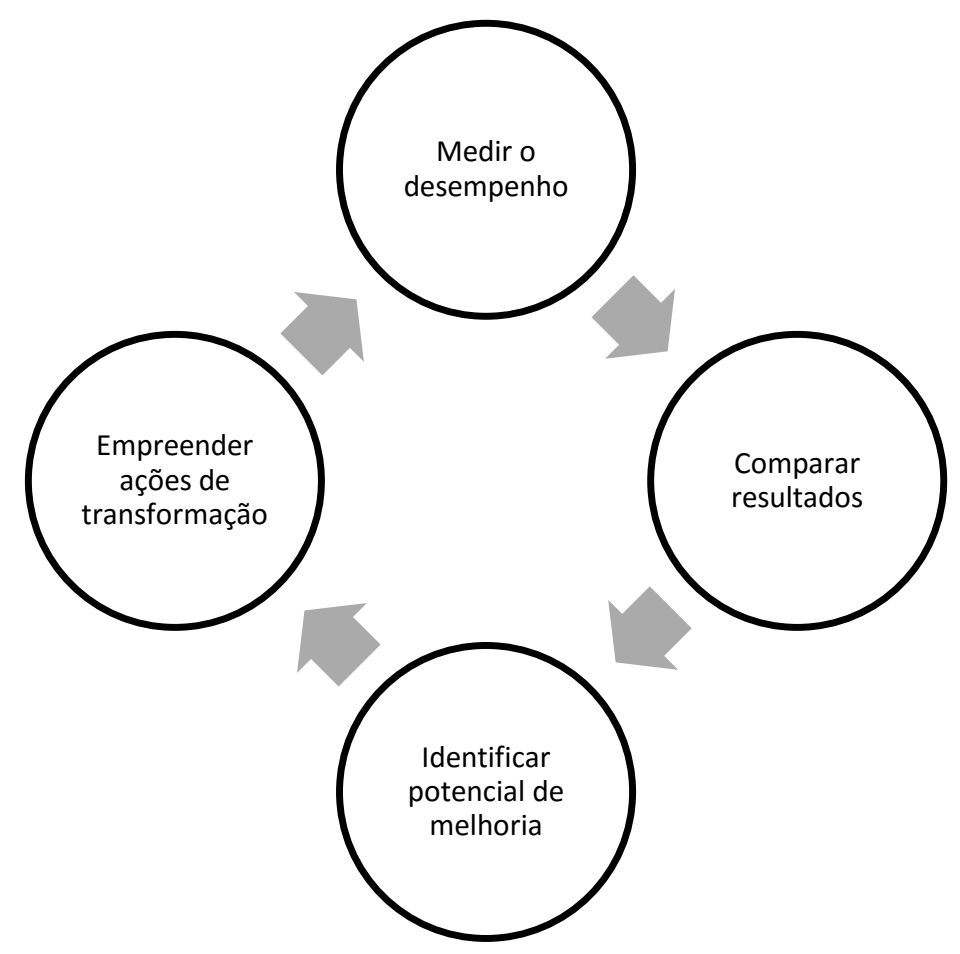

Figura 6: Ciclo de busca de melhorias práticas

Fonte: Adaptado de Assis (2009, p.15)

Palmeira (2012) afirma que indicadores não confiáveis podem ser piores que os piores resultados alcançados, pois ocultam a real situação. Assim sendo, acredita-se ser importante conhecer e analisar os indicadores que serão utilizados e ter uma visão crítica sobre a necessidade dos mesmos para a organização. Dessa forma, haverá uma razão lógica e estratégica para dispor desses indicadores, evitando assim a realização de trabalhos que não agregam para o desenvolvimento organizacional.

Os modelos de avaliação de treinamento também são tipos de indicadores de desempenho, pois mensuram satisfação, aprendizagem, mudança de comportamento, retorno de investimento, dentre outros. Contudo, há indicadores que não fazem parte desses modelos, sendo associados a outros dados de treinamento, que serão apresentados a seguir. 


\subsubsection{Indicadores de treinamento}

Os indicadores de treinamento são medidas que refletem uma realidade operacional e menos estratégica. Essas medidas eram muito valorizadas e utilizadas nos Centros de Treinamento e Desenvolvimento. Para as Universidades Corporativas elas também podem ser úteis, mas não são primordiais para seu funcionamento.

Os indicadores que refletem a realidade financeira da empresa, como a relação dos custos com o lucro operacional e com o total de empregados, são requeridos a fim de justificar a existência dos cursos de treinamento. Os insumos desses indicadores podem ser úteis para a elaboração do ROI, uma vez que se identificam os custos relativos aos treinamentos realizados.

\subsubsection{Participação das despesas de treinamento no lucro}

Esse indicador auxilia para compreender a proporção do valor destinado ao treinamento dos empregados no lucro operacional da organização. Segundo Assis (2009), alguns estudos especulam que empresas de melhor desempenho destinam em torno de $3 \%$ do lucro para investimento em programas de capacitação da força de trabalho. (ASSIS, 2009)

$\%$ Treinamento sobre o lucro $=\left(\frac{\text { Gasto com ações de treinamento }}{\text { Lucro obtido }}\right) \times 100$

Fonte: Adaptado de Assis (2009, p.80)

\subsubsection{Custo de treinamento por empregado}

É um indicador que mede o investimento das ações de treinamento. A equação envolve a divisão dos investimentos (ou custos) realizados pela empresa no período, pelo número de empregados. Caso a medição seja anual, utiliza-se o número médio de empregados no ano. (ASSIS, 2009)

Custo de treinamento por empregado $=\frac{\text { Custo total de ações de treinamento }}{\text { número de empregados }}$

Fonte: Adaptado de Assis (2009, p.81) 
Os custos decorrentes dos eventos de educação corporativa, como inscrição, pagamento de docentes internos e viagens e despesas de deslocamento, devem ser agrupados em contas separadas, para facilitar o cálculo dos indicadores, principalmente dos indicadores financeiros. (PALMEIRA, 2012)

\subsubsection{Hora de treinamento pelo número de empregados}

Esse indicador é muito usual e busca identificar o tempo médio de treinamento por empregado, pode ser nomeado por HHT (homem/hora/treinamento). Ele tenta avaliar o nível de esforço para assegurar a qualificação e o desenvolvimento permanente da força de trabalho. Normalmente é medido por hora de treinamento por ano. (ASSIS, 2009)

$$
\text { Horas de treinamento por empregado }=\frac{\text { Total de horas de treinamento }}{\text { Número total de empregados }}
$$

Fonte: Adaptado de Assis (2009, p.117)

Há variações desse indicador, uma delas é a divisão do volume de horas de treinamento pelo número de pessoas que efetivamente receberam treinamento. Contudo, se não houver o percentual de pessoas treinadas frente ao total de colaboradores, esse índice pode ocultar a realidade de que poucos têm acesso à capacitação na empresa. (PALMEIRA, 2012)

É interessante também, avaliar as diferentes necessidades das áreas organizacionais por treinamento, uma área operacional pode ter menos treinamentos do que uma área administrativa, devido à automação do processo. Aplicando o indicador abordado acima a esses grupos, expõe o quantitativo de horas de treinamento por área organizacional, o que pode servir de insumo na decisão de investimento em novos cursos. (PALMEIRA, 2012)

A avaliação de quantidade de horas investida em treinamento também pode abordar o nível hierárquico. Segundo Palmeira (2012), a comparação do HHT com os custos possibilita perceber que a alta administração possui poucas horas de treinamento, contudo seus custos são maiores, comparado aos demais, podem representar o dobro dos custos em outras esferas organizacionais. Essa análise facilita a decisão do que deve ser investido, em momentos de redução de custos. 


\subsubsection{4.Índice de empregados em programas de treinamento}

Esse indicador aponta a proporção de empregados que participaram de treinamentos, em comparação com o número total de empregados da organização. Assim, como abordado acima, por Palmeira (2012), tal índice pode exibir uma situação em que o acesso a treinamento é restrito a poucos colaboradores. (ASSIS, 2009)

$$
\text { Índice }=\frac{\text { Número de empregados nos treinamentos }}{\text { Número total de empregados }}
$$

Fonte: Adaptado de Assis (2009, p.118)

De acordo com Assis (2009), há aspectos que limitam a mensuração de indicadores relacionados ao processo de capacitação dos colaboradores da organização, como, treinamentos on job, onde o funcionário é treinado em seu local de trabalho e na função para o qual foi designado. Para reduzir essa limitação, deve-se solicitar o registro dos treinamentos e a informação para a Universidade Corporativa, a fim de facilitar na mensuração dos indicadores. (ASSIS, 2009)

Além do abordado acima, atividades de autodesenvolvimento, assumidos pelos empregados, seja por motivação própria, ou pelo conhecimento adquirido na leitura de livros, artigos e revistas são difíceis de ser mensurados e contabilizados. A solução que o autor encontra é o desenvolvimento de um indicador que tente contabilizar o esforço pelo autodesenvolvimento. Esse indicador seria de responsabilidade do empregado por manter os registros atualizados. (ASSIS, 2009)

\subsubsection{Prontidão dos líderes}

Esse indicador aborda o percentual de funcionários capacitados em programas de gestão que estão aptos a assumir posições de liderança, em relação à quantidade total de lideres; ou seja, dos líderes que estão em atuação, quantos estão preparados para tal função. (PALMEIRA, 2012)

Indicador de prontidão de liderança $=\frac{\text { Líderes capacitados em programas de gestão }}{\text { Total de lideres na organização }}$ 


\subsubsection{Tipo de treinamento versus total de treinamento}

Palmeira (2012) debate sobre a observação do investimento, em horas, em treinamento comportamental, técnico, administrativo, de sistemas, de gestão; a fim de orientar os funcionários quanto à concentração em determinado tipo, em detrimento de outro.

\subsubsection{Vagas disponibilizadas versus demanda planejada}

O percentual obtido, pela quantidade de vagas disponibilizadas, dividido pela demanda de treinamento planejada, apresenta o esforço da universidade corporativa em converter demandas em cursos. (PALMEIRA, 2012)

\subsubsection{Vagas oferecidas versus utilizadas}

A divisão das vagas utilizadas pelas vagas oferecidas indica se a demanda planejada foi superior ao que podia ter sido realizado. Essa situação pode ocorrer devido à falta de tempo dos participantes, previamente inscritos nos cursos. Isso explica o fato de muitos treinamentos planejados não serem realizados, levando ao desperdício, seja do tempo dos envolvidos na elaboração do curso, ou dos custos consequentes dele. (PALMEIRA, 2012) 


\section{Métodos e procedimentos de coleta e de análise de dados do estudo}

Este capítulo informa sobre as diversas decisões acerca da forma como este estudo foi realizado.

Está dividido em duas seções que são instrumentos de coleta de dados e forma de análise e limitações do estudo. A primeira informa sobre as fontes de informação selecionadas para coleta de dados, os processos e instrumentos de coleta de dados e as formas escolhidas para tratar e analisar os dados coletados. Já a segunda aborda as possíveis repercussões que as decisões sobre como realizar o estudo impuseram aos resultados assim obtidos.

\subsection{Instrumentos de coleta de dados e forma de análise}

Realizou-se um estudo de caso na Universidade Corporativa da Petrobras, a fim de entender, de forma mais detalhada, como é a metodologia de avaliação de suas ações educacionais. Vergara (2005) aponta que o estudo de caso é uma pesquisa limitada a uma ou poucas unidades, como um produto, uma empresa, uma comunidade ou mesmo país.

Foi realizada uma pesquisa descritiva e explicativa a fim de expor as características dessa metodologia de avaliação; quais são os motivadores dessa avaliação, quais os possíveis resultados obtidos e como eles influenciam no planejamento dos treinamentos futuros. Segundo Vergara (2005) a pesquisa descritiva expõe características de determinada população, de determinado fenômeno, ou o estabelecimento de correlação entre variáveis. Já a pesquisa explicativa visa esclarecer quais fatores contribuem para a ocorrência de determinado fenômeno.

Este trabalho utilizou de pesquisa bibliográfica, documental e de campo para coletar dados no campo estudado. Como abordado por Vergara (2005) a pesquisa bibliográfica é um estudo baseado em material acessível ao público geral, publicado em livros e revistas; esse tipo de pesquisa fornece instrumento analítico para qualquer outro tipo de pesquisa. Já a pesquisa documental como 
uma investigação em documentos de órgãos públicos e privados de qualquer natureza.

A pesquisa bibliográfica e a documental são muito semelhantes. A diferença entre ambas está na natureza da fonte, enquanto a pesquisa bibliográfica se utiliza das contribuições dos diversos autores sobre determinado assunto, a pesquisa documental utiliza materiais que não receberam um tratamento analítico, ou que podem ser reelaborados de acordo com o objeto da pesquisa.

O presente trabalho também é uma pesquisa de campo, que segundo a autora, é uma investigação empírica realizada no local onde ocorre um fenômeno ou que dispõe elementos para explicá-lo. Pode incluir entrevistas, aplicação de questionários, teses e/ ou observação participante.

O universo da pesquisa contempla os membros das equipes responsáveis pelas avaliações. Os dados da pesquisa de campo foram obtidos com o gerente do setor de avaliações e a equipe de impacto, composta por três pessoas. A escolha dessa amostra foi por tipicidade, ou seja, os elementos que são representativos da população-alvo. (VERGARA, 2005)

$O$ instrumento de coleta de dados foi entrevista presencial. Foram realizadas entrevistas focalizadas, que de acordo com Vergara (2005), permitem que o entrevistado discorra mais sobre o assunto abordado, mas sem desviar do foco principal.

O roteiro das entrevistas foi diferente para os dois grupos pesquisados. Para o gerente perguntou-se sobre levantamento de necessidade de treinamento, gestão de competência e o processo de avaliação, como se pode verificar no Apêndice 1. Já para a equipe de impacto, o questionário foi menor, com perguntas voltadas somente para o processo de avaliação, disponível no Apêndice 2. Entende-se que para esse segundo grupo não se aplicavam todos os questionamentos, já que possuem uma atuação mais operacional.

O tratamento dos dados ocorreu através da análise qualitativa das entrevistas, por meio de um procedimento interpretativo dos mesmos. Para isso, todas as conversas foram gravadas e transcritas para auxiliar no detalhamento da análise das discussões.

As informações obtidas dos respondentes e os dados documentais foram confrontados com o referencial teórico adotado na pesquisa, principalmente com a metodologia de Kirkpatrick (2010), no que se refere à avaliação dos cursos, e 
com Chiavenato (2002), em relação à identificação das necessidades de treinamento.

\subsection{Limitações do Estudo}

Ao longo do trabalho, foram identificados alguns fatores que podem limitar o estudo a ser realizado. O conteúdo das entrevistas pode ter um viés tendencioso, por mais que se tente tomar as devidas providências para a redução do mesmo.

Como as entrevistas aconteceram com os atores que realizam as avaliações das ações educacionais e dentro do seu local de trabalho, pode-se ter um receio de criticar seu próprio trabalho, levando-os, assim, a omitir algumas informações.

Além disso, devido à quantidade de entrevistados, as respostas obtidas podem enviesar os resultados; já que não participaram da entrevista todos os funcionários envolvidos no processo de avaliação.

Por fim, o entrevistador pode realizar interpretações sobre as informações ditas, que podem não estar de acordo com o que o entrevistado quis passar; 0 que leva a uma análise equivocada. 


\section{Apresentação e análise dos resultados}

Este capítulo apresenta e discute os principais resultados alcançados, analisa e debate suas implicações e produz sugestões sobre o estudo previamente selecionado.

\subsection{A Empresa}

A Petrobras foi fundada em 3 de Outubro de 1953, como resultado da campanha popular "O Petróleo é Nosso". Seu objetivo principal era explorar o recém descoberto petróleo brasileiro.

Nessa época necessitava-se de profissionais especialistas para a exploração e produção do petróleo; principalmente de engenheiros de petróleo formação não existente no Brasil até esse momento. Sendo assim, a empresa sentiu a necessidade de especializar a sua força de trabalho, e criou um setor que tinha como função a coordenação de estágios de aperfeiçoamento de pessoal no exterior e também de criação e condução de cursos de especialização em petróleo. Essa foi a primeira ação de treinamento realizada pela instituição (CALDAS, 2013)

A Petrobras criou o Centro Nacional de Aperfeiçoamento e Pesquisa de Petróleo (CENAP), e com o passar do tempo, criaram-se centros de treinamento, que foram se aperfeiçoando e se transformando em uma Universidade Corporativa, nos anos 2000.

No ano 2000, a Petrobras teve que se adaptar rapidamente para aumentar a competitividade da Companhia e diminuir as perdas do mercado. Diante desse contexto, realizou parcerias para preparar técnicos e gerentes para o trabalho conjunto com outras empresas nos negócios; e o projeto internacionalização, que visa preparar os gerentes e técnicos para a atuação no mercado externo.

A Universidade Corporativa da Petrobras foi criada em 2000, tornando-se o principal órgão para treinamento e desenvolvimento da empresa. O seu desafio 
foi oferecer ações educacionais de qualidade para o crescente número de profissionais admitidos, capacitando-os para a execução de seus trabalhos.

Somente em 2005, após uma reestruturação, a Universidade Corporativa se tornou Universidade Petrobras (UP). Entre o período de 2006 e 2013, a Universidade Petrobras teve um grande crescimento, mais de quatrocentos empregados passaram a compor a sua equipe; responsáveis por mais de 1.500 cursos diferentes de educação continuada, além da formação de novos funcionários na empresa. Nessa época, a Universidade também passou a ter parcerias com instituições de ensino no Brasil e no exterior. (CALDAS, 2013)

Nesse contexto criou-se a Gerência RH/UP/DRH, Gerência de Desenvolvimento de Recursos Humanos (DRH), que assumiu o papel de orientador corporativo de $\mathrm{DRH}$, com responsabilidade de atender aos processos corporativos de capacitação e aos programas externos que a Petrobras apoia.

O setor de $\mathrm{DRH}$ assume o processo denominado de Planejamento de Desenvolvimento de Recursos Humanos (PDRH), que tem como objetivo mapear as necessidades de capacitação dos empregados.

Nesse mesmo período a Universidade Petrobras foi reestruturada, contando agora com Escolas de Gestão, Técnica e de Ciências e Tecnologias, como apresentado na figura 7. As Escolas da Universidade Petrobras são gerências que preparam os programas educacionais específicos para cada unidade de negócio da empresa.

A UP oferece dois tipos de educação. Os cursos de formação, voltados aos profissionais recém-admitidos, que ensinam sobre o negócio da empresa, as competências básicas e as específicas de cada função com o objetivo de formar funcionários para atuarem na realidade da Petrobras. E a Educação Continuada, que são cursos para desenvolver os profissionais já atuantes na instituição, segundo a identificação de suas necessidades de capacitação.

Segundo Caldas (2013), a UP estabelece uma política de qualidades com algumas prioridades:

Em sua política de qualidade, a UP tem estabelecido como prioridades: a qualidade na disseminação do conhecimento; o pleno alinhamento das soluções educacionais aos planos de negócio e gestão da companhia; a otimização e a disciplina de capital no uso dos recursos; a valorização das pessoas; e a adoção de processos simplificados e aperfeiçoados continuamente. Planejamento, metas, indicadores de desempenho e gestão de custos fazem parte dessa nova realidade. (CALDAS, 2013, p. 100)

A Universidade Petrobras mantém, desde 2005, um sistema de gestão certificado pelos critérios da Norma ISO 9001. Essa Norma assegura a adoção 
de processos estruturados e uniformizados e a qualidade dos seus cursos e sua gestão.

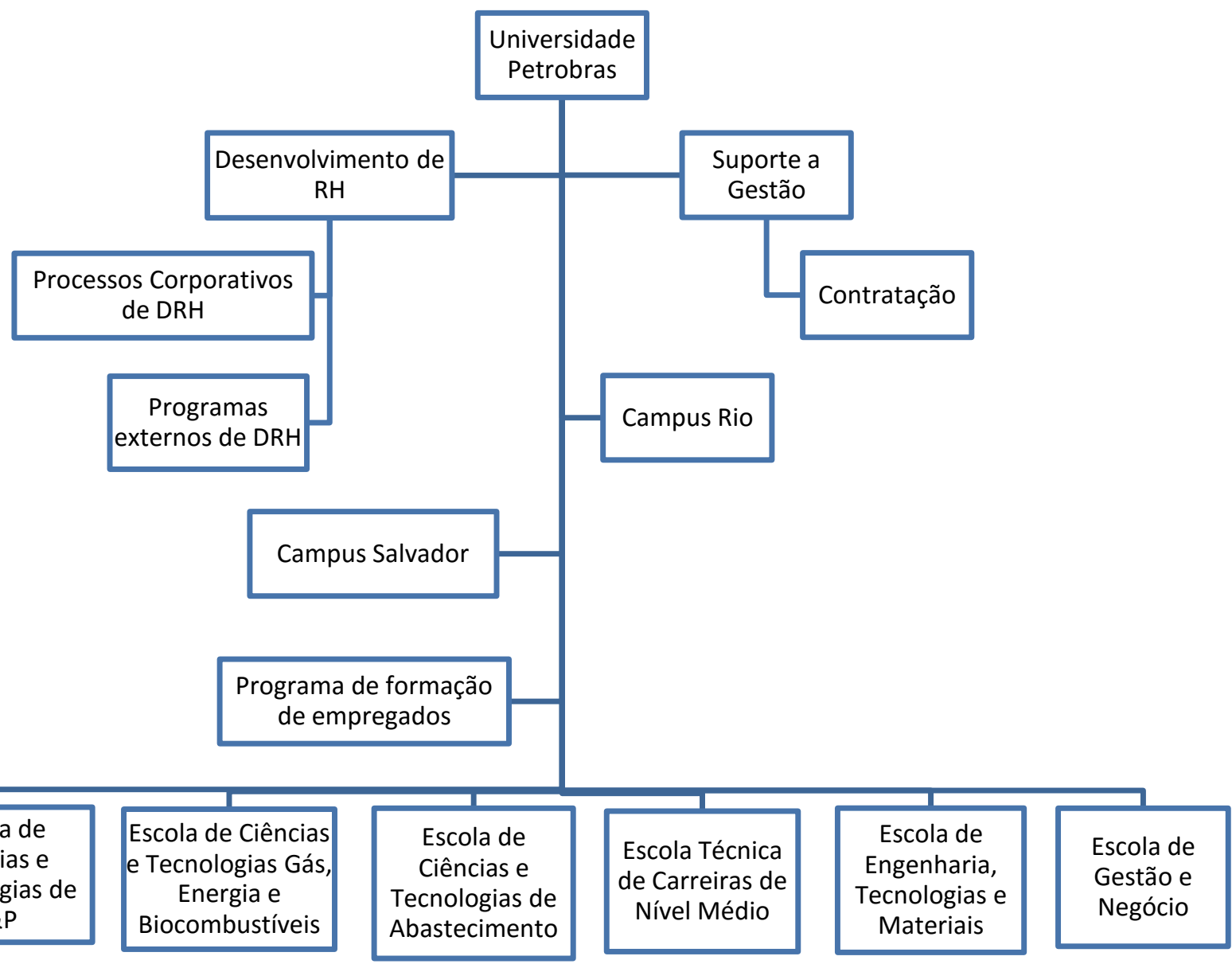

Figura 7: Organização da Universidade Petrobras

Fonte: Caldas (2013, p. 98) 


\title{
4.2.Descrição e análise dos resultados
}

As informações obtidas nessa pesquisa provieram de entrevistas com 0 gerente do setor de Desenvolvimento de Recursos Humanos (DRH), com a equipe de impacto, composta por uma coordenadora, uma analista e uma estagiária; e dos documentos organizacionais disponibilizados, como formulários das avaliações realizadas e relatórios empresariais.

O gerente é responsável pela área de $\mathrm{DRH}$ e responde pelos indicadores de desempenho, avaliações de ações educacionais e mapeamento das necessidades de capacitação dos empregados. Já a equipe de impacto, que compõem a área de $\mathrm{DRH}$, realiza somente a avaliação de impacto.

$\mathrm{Na}$ sequência serão apresentadas as análises das informações obtidas através do estudo de campo, pesquisa bibliográfica e documental.

\subsubsection{Levantamento da necessidade de treinamento}

O levantamento de necessidade de treinamento na Universidade Petrobras é realizado a partir do Plano de Desenvolvimento Individual (PDI) do empregado. No PDI avaliam-se as capacidades competentes aos empregados e aquelas que precisam ser desenvolvidas para o desempenho das atividades e adequação à estratégia organizacional. $\mathrm{O}$ gerente de DRH explicou que a execução desse trabalho realiza-se da seguinte forma:

\begin{abstract}
O empregado faz uma auto avaliação, no contexto competência e no contexto avaliação de desempenho. Os resultados desse processo de avaliação são utilizados pelo gestor para a elaboração do PDI do empregado. A elaboração é feita com a colaboração do empregado, opinando em cursos que sejam de seu interesse, a fim de melhorar seu desempenho.
\end{abstract}

Através do PDI, realiza-se o Planejamento e Desenvolvimento de Recursos Humanos (PDRH). Segundo o entrevistado:

Esse $\mathrm{PDRH}$, basicamente, é um questionamento que fazemos à unidade, para que ela nos informe, baseado no que são as metas do empregado, as competências críticas, estratégicas, o que ela precisa de desenvolvimento; quais são os conhecimentos relevantes pro processo, o que que é desdobramento da estratégia; o que as unidades precisam de atendimento em desenvolvimento de recursos humanos.

De acordo com o gerente, "o PDRH é a soma dos PDIs". Ele consolida as necessidades de treinamento identificadas, o que pode ser modificado ao longo do ano, conforme as necessidades. No portal Petrobras o planejamento do 
PDRH é descrito como um plano que deve considerar o Plano Estratégico e de Negócios da Petrobras, os processos críticos da gerência, competências e metas individuais, e melhorias de rotina a desenvolver.

Um documento de apresentação empresarial que orienta os empregados para a elaboração do PDRH revela que:

\begin{abstract}
(...) ० RH/UP disponibiliza uma lista de cursos que você escolherá considerando suas atividades, suas metas, as metas de sua gerência, sua disponibilidade de tempo e custos. A relação de cursos do RH/UP é enviada na fase do planejamento do PDRH e é atualizada ao longo do ano. (...) você poderá também procurar em instituições externas (universidades, sites, etc...) eventos que complementem a programação disponibilizada pelo $\mathrm{RH} / \mathrm{UP}$.
\end{abstract}

As ações educacionais são indicadas pelos gestores aos seus funcionários, a partir das avaliações de competência e desempenho do empregado. $\mathrm{O}$ gestor consolida as demandas de sua equipe e informa para o Planejamento e Desenvolvimento de Recursos Humanos quais os cursos, que foram previamente planejados, serão utilizados pela área.

O planejamento dos cursos é realizado em uma instância chamada Sistema Educacional Petrobras (SEP), no qual representantes das unidades organizacionais com os representantes da Universidade Petrobras discutem quais serão os programas de ações educacionais oferecidos.

O SEP é um fórum anual, com encontros presenciais, onde, além da estruturação dos cursos, também se discute temas como o processo de negócio da companhia, o atendimento das demandas, quais as maneiras para realizar esse atendimento e qual o retorno proveniente das demandas do exercício anterior.

Complementando a informação acima, o gerente de DRH disse:

\footnotetext{
A gente oferece uma carteira, a partir da discussão que teve anteriormente no Sistema de Educação da Petrobras (SEP). A gente se dimensiona para atender a demanda, conforme a consolidação do PDRH. Em um momento identifico no que preciso treinar e, no outro a quantidade que preciso investir para que esses treinamentos atendam quem realmente precisa.
}

O planejamento da demanda deve ser registrado em um sistema interno, no qual é necessário informar, dentre outros itens, o nome do curso, a competência que se pretende desenvolver com essa ação educacional, o objetivo estratégico que está embasando essa decisão e os custos provenientes dessa ação de desenvolvimento. 


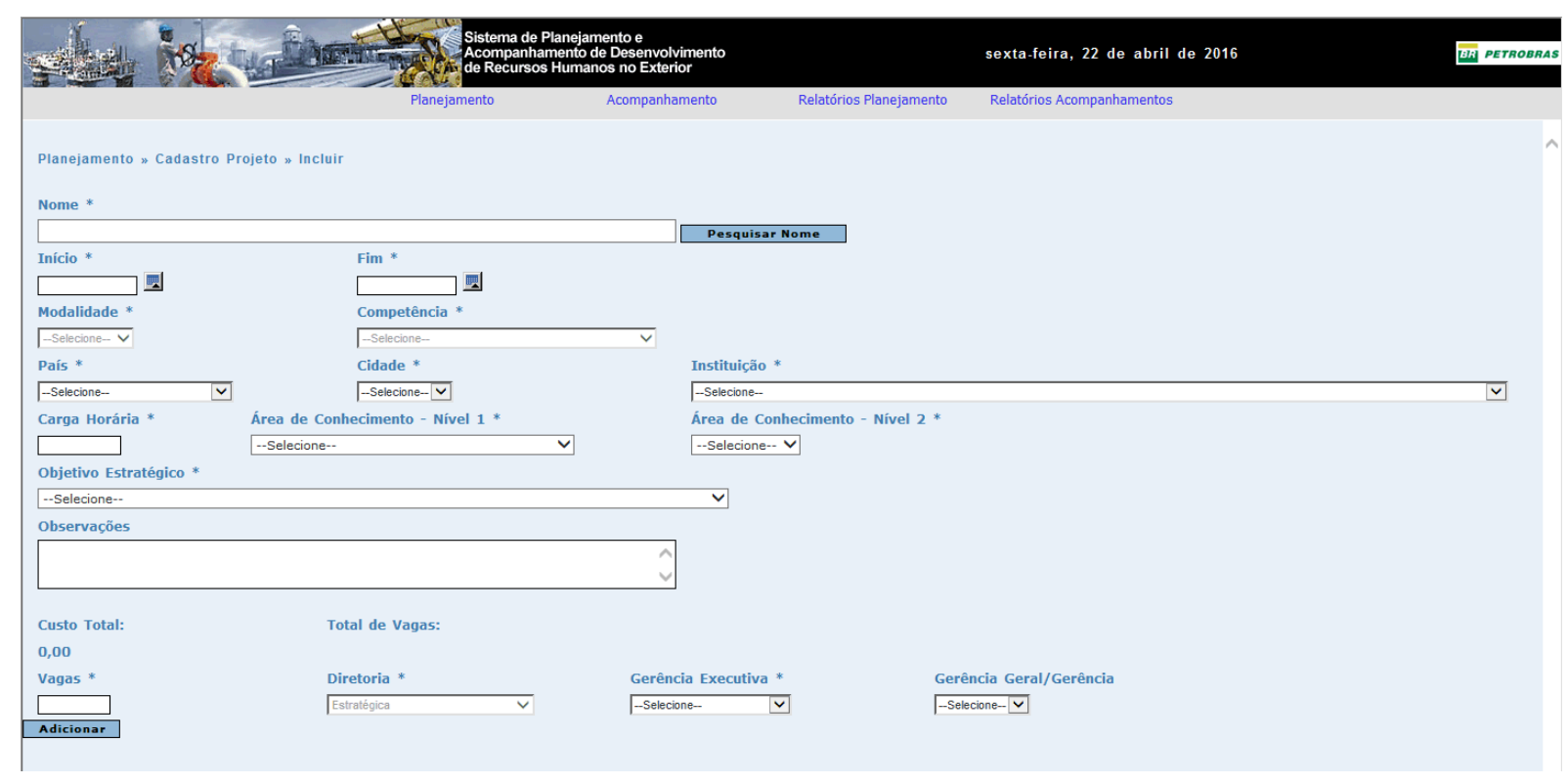

Figura 8: Sistema de DRH

Fonte: Documento Interno da Petrobras (2016)

\subsubsection{Programas educacionais}

A Universidade Petrobras atende $30 \%$ do volume de capacitação da companhia; $70 \%$ é atendido através de cursos organizados pela área ou em companhias externas. A UP atende somente o que faz parte do processo de negócio da empresa. As áreas possuem liberdade para buscar os programas educacionais que melhor supram suas demandas; caso não seja disponibilizado pela UP, elas podem procurar em uma instituição de ensino. Essa autonomia é conquistada, pois cada unidade possui um orçamento anual que é destinado para ações educacionais; ou seja, esse gasto não interfere no orçamento da Universidade.

As áreas atendem o grosso da capacitação, o grosso do treinamento, que é em torno de $70 \%$, se dá muito em função dos treinamentos legais e normativos, são para atender as normas e portarias do Ministério do Trabalho, a ANP, IBP, os órgãos que de um modo geral controlam as nossas atividades. Então os cursos legais e normativos acontecem por iniciativa das áreas.

O entrevistado abordou que diante do momento em que a empresa está vivendo e da reorganização da companhia, essa situação pode mudar. Planejase que se tenha um $\mathrm{RH}$ centralizado e a relação de independência presente hoje na companhia pode modificar. A realidade atual é que cada setor tem seu $\mathrm{RH}$ 
que cuida dessa parte de desenvolvimento das pessoas, e os gastos e planejamentos com ações educacionais devem ser comunicados somente para esse $\mathrm{RH}$ setorial, não é preciso informar à UP ou ao $\mathrm{RH}$ corporativo (que não lida com ações de capacitação dos profissionais).

Muitos dos cursos oferecidos pela Universidade estão voltados para desenvolver capacidades técnicas, isso, segundo o entrevistado, pode ser resultado da natureza da companhia e da peculiaridade do conhecimento que eles precisam ter. Contudo, há ações que desenvolvem o comportamental, como - Desenvolvimento de Gestores (DG), que basicamente é focado em competências comportamentais vocacionadas às lideranças.

Outro exemplo que foi dado de programa educacional que desenvolve a capacidade comportamental é o Programa de Desenvolvimento de Competências Individuais (DCl). Nele desenvolvem-se temas como trabalho em equipe e orientação para o cliente, desde em cursos tradicionais e presenciais, com peças de autoestudo, EADs (Ensino a Distância) institucionais, livros e vídeos; até em um estágio supervisionado. Se a demanda for por trabalho em equipe, o profissional pode fazer o job rotation em uma área, e atuar em três equipes distintas para perceber as diferenças e as necessidades de trabalhar em equipe.

$\mathrm{Na}$ organização não é utilizado o conceito de tipos de capacitação obrigatórios e eletivos. O que eles entendem por obrigatório são programas educacionais considerados legais e normativos. São realizados, caso uma agência reguladora exija uma certificação do funcionário para realizar determinada tarefa. O exemplo dado pelo entrevistado é que "o Ministério do Trabalho diz que para um empregado trabalhar numa plataforma de petróleo, ele tem que ser certificado na norma NR-33, que é trabalho confinado. Se ele não tiver esse certificado na mão, ele não embarca, ai é obrigatório.”.

O gerente ainda abordou que há ações educacionais que se tornam obrigatórias por tempo determinado, por uma situação momentânea, como o Programa Petrobras de Prevenção à Corrupção (PPPC). São realizados para capacitar e conscientizar os empregados, devido à situação atual.

É um treinamento que a força de trabalho inteira tem que fazer, mas isso não parte propriamente do processo de desenvolvimento de recursos humanos. Isso é muito mais uma orientação que vem da diretoria, vem da presidência, a partir de algum apontamento específico, enfim é dissociado do processo de trabalho do empregado. 
Esse tipo de capacitação, considerada momentânea pelo entrevistado, pode ser confrontado com a necessidade de treinamento provenientes de indicadores a posteriori, como abordado por Chiavenato (2002). O autor aborda que esses indicadores são os problemas provocados por capacidades não atendidas; que ao ocorrerem, indicam que há necessidade de capacitar.

O conceito de competências é importante para montar a grade de programas educacionais do empregado. Contudo, o entrevistado faz uma crítica ao modelo de competências atual da empresa, que ainda é muito técnico e pouco estratégico.

\begin{abstract}
Eu te diria que hoje, mais do que nunca, a gente está aprendendo que a gente precisa simplificar o nosso modelo de competências, ele é um modelo de competências ainda muito focado no que a gente chamaria de competências estritamente técnicas, quando na verdade a gente tem que migrar para um modelo de competências estratégicas. Menos competências e mais ligadas diretamente ao objetivo estratégico. Hoje a gente tem mais competências ligadas diretamente às atividades dos empregados no processo de trabalho. Então a gente tem que fazer uma transição ai e isso a gente está discutindo no $\mathrm{DRH}$ ainda.
\end{abstract}

Diante dessa falha de priorizar capacidades técnicas, o gerente de $\mathrm{DRH}$ afirma que a UP ainda tem uma essência de Centro de Treinamento. Ele aborda que a empresa ainda está em transição para serem um Sistema de Educação Corporativa. E o que está dificultando esse processo é a quantidade de competências técnicas da companhia, que totalizam 2.500. O entrevistado abordou que as novas competências devem ser ligadas à cadeia de valor da organização, ligadas aos processos de negócio. Fazendo essa transição, a estimativa é que se reduzam para 200 competências organizacionais.

\footnotetext{
Então eu te diria que a gente ta nesse momento de transição ainda, buscando um pouco de identidade, mas saindo de um Centro de Treinamento e indo para um Sistema de Educação Corporativa. (...) a Universidade Petrobras (...) não é o único elemento do Sistema de Educação Corporativa, as unidades, os gestores dos empregados, todo mundo passa a ser um elemento de Sistema de Educação Corporativa.
}

Ao ser indagado sobre essa redução de quantidade de competências, o gerente afirmou que estão trabalhando junto ao $\mathrm{RH}$ Corporativo para que isso se torne realidade. "Tudo isso está muito perspectivo agora, em função da reorganização. A gente já sabe que vai ter uma área dentro do $\mathrm{RH}$ chamada CCS - Conhecimentos, Competências e Sucessão." O planejamento é que essa nova área estabelecerá um diálogo natural com a Universidade Petrobras para rever esse modelo. 


\subsubsection{Avaliação das ações educacionais}

As ações educacionais gerenciadas dentro da Universidade Petrobras são avaliadas de três formas: reação, aprendizagem e impacto. Essas ações educacionais, como já apresentado, representam $30 \%$ do volume de capacitação de toda a Petrobras.

Diferente do sugerido por Kirkpatrick (2010), essas avaliações não ocorrem de forma sequencial. Elas são analisadas por equipes diferentes, que não se comunicam e nem repassam as informações. Dessa forma não é possível ver as interligações entre as avaliações, nem analisar se uma determinada atitude pode ter sido influenciada por uma reação negativa ou uma má aprendizagem do participante.

Não há uma equipe específica para a consolidação das informações obtidas nas avaliações de reação e de aprendizagem. Somente para a avaliação de impacto, que é mais trabalhosa e demanda mais atividades, há uma equipe composta por três pessoas.

A seguir será explicado como é realizado o processo de avaliação.

\subsubsection{Avaliação de Reação}

$\mathrm{Na}$ reação busca-se avaliar as condições de entrega do conhecimento. Avalia-se a adequação do material didático, a didática do professor, as instalações da sala, ou seja, o conjunto de recursos que foram empregados para entregar o programa educacional. A avaliação é voluntária, não é censitária, e baseada nela procura-se aperfeiçoar o serviço.

Justificou-se que a reação não era censitária, pois ao torná-la obrigatória, isso a descaracterizaria. O gerente de DRH ainda afirmou que "(...) a gente nota que quando ele quer responder, ou ele está muito satisfeito ou muito insatisfeito, são os dois extremos da escala que respondem a avaliação de reação. E ela meio que se equilibra.".

A avaliação de reação, disponível no Anexo 1, é entregue aos participantes através de um formulário automatizado. Ao terminar o curso e obterem a listagem dos participantes, envia-se um e-mail com o formulário em um sistema interno da Petrobras. As informações obtidas ficam em posse da UP e, caso haja uma solicitação, entregam-se essas informações aos clientes. $O$ entrevistado 
justificou que a consolidação das informações não é devolvida individualmente aos alunos, porque há um grande volume de respostas.

Os resultados desse tipo de avaliação são consolidados, refletidos no Índice de avaliação de reação global dos eventos e encaminhados para as Escolas, que preparam os cursos.

Kirkpatrick (2010) sugere que o formulário ideal para esse nível de avaliação forneça o máximo de informações e exija o mínimo de tempo. "Quando um programa termina, a maioria dos treinandos está ansiosa para ir embora e não quer passar um longo tempo preenchendo formulários de avaliação." (KIRKPATRICK, 2010, p. 45).

Esse formulário deve ter perguntas diretas sobre como se avalia o tema do programa educacional, o instrutor, o cronograma e instalações, com escalas, como de 0 a $100 \%$, ruim a excelente. Assim facilita-se o preenchimento do participante.

Isso só dá parte das reações dos participantes, pois não se saberá o motivo dessas reações, nem sugestões de melhorias. Para tal, é importante ter um campo para que se escreva essas sugestões.

O autor ainda aborda que quando se entrega o formulário no final do curso, caso os participantes estejam apressados para saírem, esse campo de sugestões pode ser ignorado por boa parte dos treinandos. Uma forma de evitar isso é entregar o formulário antes do término do curso, disponibilizando um tempo para seu preenchimento e informar a importância dessa ação.

O formulário de reação da Universidade Petrobras condiz com o que é sugerido por Kirkpatrick. As perguntas trazem informações relevantes para a melhoria dos programas educacionais e as escalas de avaliação, facilitam as respostas dos respondentes, além de requererem pouco tempo para as mesmas.

Contudo, a avaliação não ocorre logo após a realização do curso, como é sugerido pelo autor acima. Isso pode culminar no menor número de respondentes, e os que responderem podem não refletir a realidade do todo; pois eles podem enviesar a pesquisa ou por estarem contentes com o que foi apresentado ou por estarem muito insatisfeitos, ou por não lembrarem mais, em detalhes, do curso oferecido.

Dessa forma, acredita-se que, por mais que dificulte a contabilização dos resultados, o melhor seria entregar um formulário impresso ao final de cada 
curso; seguindo a sugestão de Kirkpatrick para disponibilizar um tempo para essas respostas, salientando a importância das sugestões de melhoria.

A partir da consolidação dos dados, deve-se analisar os aspectos do programa e comparar com os padrões esperados. Caso seja abaixo do esperado, avaliar as sugestões de melhorias para saber o que pode ser feito. Em relação à comunicação das reações para os interessados, Kirkpatrick (2010), sugere que seja analisada a importância dessa informação para essas pessoas e o que deve ser comunicado. Só deve ser comunicado algo que seja importante e afete o trabalho de uma área ou de um funcionário.

O entrevistado ainda afirmou que a análise dos resultados com os padrões esperados pelos programas educacionais não é realizada em seu setor, mas sim pelas Escolas da UP que realizaram seu planejamento e elaboraram a ementa dos cursos. Na gerência de DRH só é realizada a consolidação dos dados provenientes das avaliações.

Acredita-se que as mudanças provenientes dessa avaliação possam ser disponibilizadas para os participantes, pois isso gera um retorno concreto do esforço despendido em avaliar.

\subsubsection{Avaliação de Aprendizagem}

A avaliação de aprendizagem serve para identificar o que o empregado assimilou do conhecimento que foi transmitido. Na Universidade Petrobras ela ocorre em todos os cursos, e pode ser feita de diversas formas, como: prova, trabalhos (individuais ou grupais) e trabalho de conclusão de curso - no caso dos cursos de pós-graduação.

Esse método de avaliação, no campo estudado, não possui um parâmetro fixo, cada professor define a metodologia que acredita ser a melhor para mensurar a aprendizagem. Com a execução do método, estabelece-se um critério mínimo para a aprovação do profissional no curso, sendo que, muitas vezes esse critério é uma nota estabelecida pelo professor. Quando não se atinge essa nota mínima, o profissional não recebe o certificado de conclusão de curso, não sendo, assim, apto a praticar o que foi ensinado.

A avaliação de aprendizagem mensura, através de notas, o grau de conhecimento que o profissional obteve a partir da realização de uma ação educacional. Essa mensuração é importante, pois a mudança no comportamento 
do profissional ocorrerá, dentre outros fatores, se ele aprendeu e entendeu as ferramentas que o auxiliará a mudar sua atitude no trabalho.

Os resultados da avaliação são enviados para outra gerência da Universidade Petrobras, as Escolas da UP, onde são tomadas as devidas providências, sem dar conhecimento para o setor de $\mathrm{DRH}$.

Acredita-se que seria importante os resultados obtidos nessa avaliação serem repassados para o setor de Desenvolvimento de Recursos Humanos, pois poderia investigar uma correlação entre os resultados obtidos com a avaliação de aprendizagem e reação. Por exemplo, o profissional pode não ter aprendido o conteúdo ensinado, devido a uma insatisfação com a didática do professor. Dessa forma, pode ser estabelecida uma relação de causa e consequência entre os fatos. Esse fato sendo comprovado serve de insumo para futuras mudanças e melhorias das ações educacionais.

Uma sugestão feita por Kirkpatrick (2010) nesse nível é uma pré-avaliação com o conteúdo que será abordado no curso, e uma pós-avaliação, com o término do mesmo, o que facilita a identificação do que foi aprendido pelos participantes. O gerente de DRH afirmou que essa é uma vontade que eles possuem, de fazer uma pré-avaliação. Contudo, ainda não é uma realidade da organização.

\subsubsection{Avaliação de Impacto}

A avaliação de Impacto é uma medição do impacto de uma ação de desenvolvimento no processo de trabalho do empregado. Ela é realizada de forma amostral e ocorre nos cursos com carga mínima de 16h e mínimo de 15 participantes. De acordo com a coordenadora dessa avaliação "o objetivo da avaliação de impacto é saber, após o término do curso, o quanto aquilo está sendo efetivo no processo de trabalho.".

Os objetivos referentes a essa averiguação, identificados no documento da UP são:

- Observar o impacto de um curso nos empregados;

- Identificar mudanças comportamentais, melhoria no desempenho e agilidade no processo de adaptação do novo empregado;

- Constatar possíveis resultados do negócio, fornecendo medidas de retorno do investimento na economia de tempo e custo no desenvolvimento do empregado; 
- Obter insumos para manutenção e melhoria dos cursos, a partir da observação dos egressos e seus gerentes em relação aos conteúdos trabalhados e sua aplicabilidade no processo de trabalho.

Pode-se concluir que essa avaliação tenta englobar os níveis 3 e 4 de Kirkpatrick, que são comportamento e resultados. Essa metodologia é desenvolvida pelo $\mathrm{RH}$ da Universidade Petrobras e aplicada em cursos de formação e educação continuada cerca de três meses a um ano após o término do curso, por meio de questionário.

A avaliação ocorre de maneira amostral, por ser onerosa se for realizada para todos os cursos. São enviadas perguntas para os participantes dos programas educacionais e seus gestores, para analisarem o quanto o programa foi relevante para a melhoria do desempenho do empregado. $O$ envio desse questionário é automatizado, online para os participantes e através do sistema SPS, que é um sistema interno, para os gerentes.

A avaliação de impacto se torna onerosa, segundo a coordenadora de impacto, pois demanda muito tempo e esforço para a consolidação dos dados. Além disso, para que se obtenha um número considerável de respondentes, muitas vezes é necessário um esforço para conscientizar o público alvo da importância de contribuir para a avaliação.

\footnotetext{
Então, a gente procura mensurar o impacto do treinamento na atividade de trabalho, na atividade do empregado, baseado no feedback do próprio empregado que veio treinar e no gestor que acompanha o empregado antes e depois do treinamento. (Gerente de $\mathrm{DRH})$
}

A escolha da amostra acontece através de uma definição dos cursos mais estratégicos para a Universidade Petrobras, e a partir desse primeiro filtro, faz-se um sorteio dos cursos que serão avaliados. Em média sorteiam-se cinquenta cursos para sofrerem essa análise, vinte e cinco para cada semestre.

No período de três meses até um ano após o curso, será aplicada a avaliação. Segundo a coordenadora de impacto, é preciso dar esse tempo para que o conhecimento adquirido possa ser aplicado.

(...) eu não posso fazer essa avaliação logo depois que ele sair daqui porque não faria sentido, o gestor tem que observar o empregado desempenhar depois do curso e o próprio empregado tem que avaliar sua capacidade após a entrega do curso. (Gerente de DRH) 
A resposta para essa avaliação também é voluntária, mesmo porque o fato de ser aplicada depois de um tempo razoável após o termino do curso, via sistema e online, dificulta a obrigatoriedade do retorno. Por isso, há parâmetros estatísticos que confirmam, ou não, a validade das respostas. Segundo o gerente de $\mathrm{DRH}$, deve-se ter em torno de $45 \%$ do total de alunos respondentes e $30 \%$ dos gestores para que a pesquisa seja validada. Atualmente, segundo a analista de impacto, o índice de respostas é em torno de $80 \%$ dos alunos e $45 \%$ dos gestores.

Analisando as perguntas que medem o impacto, disponíveis nos Anexos 2 e 3, percebe-se que elas têm características para avaliar o curso e identificar mudanças no comportamento e desempenho do empregado. Há poucos questionamentos, no formulário de impacto, que mensuram os resultados organizacionais, indagando se houve percepção de melhoria em resultados, custos e utilização do tempo/recursos.

Percebe-se que não há questões para avaliar se 0 ambiente organizacional foi favorável para a aplicação do que foi aprendido e se houve resistência ou impedimentos na gerência para que o conhecimento adquirido fosse posto em prática. Conforme salienta Kirkpatrick (2010) é importante averiguar o ambiente em que o participante está inserido, pois pode ser um ambiente de desestímulo ou coibição.

O gerente de DRH informou que para mitigar o risco identificado acima, nos programas de desenvolvimento de líderes, tenta-se abordar a importância de suportar os funcionários para praticarem o que foi aprendido e como essa atitude pode ajudar na melhoria do desempenho organizacional.

A equipe de impacto utiliza indicadores oriundos da avaliação de impacto, que serão explicados a seguir:

- Atualização do curso com a realidade Petrobras - o quanto o curso é atualizado com a realidade da Petrobras, pergunta-se se o que foi aprendido está relacionado com o que acontece na empresa;

- Satisfação dos empregados e gerentes;

- Atendimento aos objetivos - avaliar quanto do objetivo inicial do curso percebe-se que foi atendido, ao término dele;

- Economia de tempo - pergunta-se se ao invés do participante ter feito o curso, quanto tempo ele levaria para aprender o assunto;

- $\mathrm{ROI}$ - é medido através da economia de tempo x investimentos realizados. 
Todos esses indicadores são provenientes do formulário de avaliação de impacto, que é entregue aos participantes e aos gerentes. Pode-se perceber que há índices, como a satisfação do empregado e o atendimento aos objetivos, que refletem resultados de reação do empregado em relação ao curso oferecido, e não o impacto do curso na realidade profissional.

Segundo um documento de apresentação empresarial, o ROI, é calculado da seguinte forma:

$$
R O I=\frac{\text { Economia }- \text { Custos }}{\text { Custos }} \times 100
$$

- Economia: Tempo economizado (estimado pelos respondentes) X custo do tempo empregado em sala de aula

Utilizam-se custos históricos conhecidos e possíveis de serem divulgados:

- Custo do curso;

- Custo dos empregados em sala de aula - salário multiplicado pelo índice de benefícios e impostos;

- Custo da avaliação - salário-hora dos empregados que conduziram a avaliação estimada mensalmente ao longo do trabalho.

O ROI utilizado pela UP se diferencia daquele sugerido por Phillips (2007) no fator benefícios, que para o autor é a mensuração das mudanças decorrentes da capacitação oferecida. Esse valor, para Phillips (2007), engloba redução de desperdício, redução de retrabalho, lucro proveniente do desenvolvimento realizado, que são facilmente convertidos em valores monetários e satisfação no trabalho, lealdade dos funcionários, que são mais difíceis de mensurar. Já a UP substitui benefícios por economia, que compõe somente a economia de tempo.

$$
R O I=\frac{\text { Benefícios líquidos }(\text { benefícios }- \text { custo })}{\text { Custos }} \times 100
$$

Fonte: Palmeira (2012 apud Philips, 2013)

O ROI, segundo a analista de impacto, não é um indicador principal, mas é mensurado somente para os cursos de formação realizados na empresa. Segundo ela, só ocorre nesse tipo de ação educacional, porque apresentam os valores dos salários dos empregados recém-admitidos. Com o valor da 
economia de tempo e do salário, é possível medir o ganho que a empresa teve e correlacionar com os custos despendidos para a execução desse curso.

O ROI, de acordo com a visão do gerente de $\mathrm{DRH}$, é um indicador que não merece tanta visibilidade, pois ele pode estar tentando mensurar algo que não é possível, devido à intangibilidade do resultado da ação educacional.

\begin{abstract}
Em educação corporativa, honestamente, ou eu acredito ou eu não acredito. Acho que o melhor que a gente pode fazer para comprovar, e mesmo assim ela é muito mais uma elação do que uma afirmação (a partir de números) que a educação corporativa funciona, é avaliar o antes e o depois. Simples assim, não precisa elucubrar o ROI. Eu acho o ROI também muito mecanicista, muito voltado para a lógica do treinamento.
\end{abstract}

O ROI medido pela Universidade Petrobras não parece mensurar, de fato, o retorno sobre o investimento, pois os valores monetários utilizados como resultados tem como base uma estimativa de ganho de tempo. Não representa todos os benefícios obtidos através do programa educacional, como redução de desperdício, de retrabalho, aumento dos lucros e satisfação no trabalho, tal qual defendido por Phillips (2007).

Com a consolidação dos resultados obtidos, enviam-se todas as informações provenientes dessa avaliação para as Escolas tomarem as providências cabíveis.

\footnotetext{
Quando nós enviamos os resultados, nós damos a sugestão, das pessoas responsáveis informarem, se a partir daquela avaliação alguma coisa foi alterada. E ai, a Escola muitas vezes nos dá esse feedback, dizendo "melhoramos um conteúdo, modificamos alguma disciplina, aumentamos a carga horária, diminuímos, trocamos o professor", a gente tem esse tipo de retorno, e vem da escola. (Analista de Impacto)
}

Com o retorno das Escolas com as melhorias provenientes dessa avaliação, e o respaldo da mesma, envia-se um infográfico, o modelo está no Anexo 4, com uma consolidação das informações obtidas e das modificações realizadas. Objetivo do curso, economia do tempo, método de ensino e satisfação do empregado são alguns itens abordados no relatório de avaliação de impacto.

Com esse retorno para os entrevistados, a equipe de impacto acredita que, além de mostrar a efetividade da avaliação, também pode sensibilizar os que foram relutantes em responder.

Tem pessoas que não acreditam que vão receber. Muitas pesquisas acontecem e as pessoas não recebem os resultados. Nós mostramos o resultado. Ela vai perceber que ela se omitiu de algo que aconteceu, teve resultado. (Analista de Impacto) 
A avaliação de impacto mensura mais fatores relacionados à mudança do comportamento do funcionário do que os resultados obtidos. Essa avaliação está refletindo o nível 3 da metodologia de Kirkpatrick (2010). O autor aborda que avaliar os resultados, nível 4, é um processo difícil e, para tal, devem ser consideradas perguntas como: o quanto se aumentou a produtividade, qual o resultado dos programas educacionais sobre comunicação interpessoal e relações humanas, quanto a produtividade contribuiu para os lucros e até que ponto o programa educacional impactou na melhora da qualidade de vida no trabalho.

\subsubsection{Indicadores}

$\mathrm{Na}$ Universidade Petrobras há outros indicadores que refletem as avaliações das ações educacionais, bem como alguns índices gerais.

Da avaliação de impacto, extrai-se o Índice de Aplicação dos Conteúdos na Universidade Petrobras (IACUP), que reflete a aderência dos conteúdos ao processo e no trabalho do empregado. Atualmente a aderência a esse índice pela organização é de $73 \%$.

A avaliação de aprendizagem não tem um parâmetro fixo, pois depende do resultado da avaliação do professor. Já a reação é uma escala de 0 a 5 e, para se considerar o desempenho da solução educacional adequado, o índice tem que ser igual ou maior a 4,5.

Os itens da política de qualidade da Universidade Petrobras são desdobrados em objetivos da qualidade, que se refletem nos indicadores a serem atingidos, através das metas estabelecidas, como apresentado na tabela 2.

A política de qualidade retrata uma estratégia da empresa em relação às ações educacionais. Dessa forma, os indicadores mensuram se a empresa está conseguindo atingir os objetivos organizacionais.

A empresa também utiliza outros indicadores de treinamento, que não estão disponíveis na tabela abaixo. Há o HHT (homem/hora/treinamento), que acompanha o volume de treinamento por profissional. Mede-se também um indicador nomeado de Total de Participações na Universidade Petrobras, ele mensura quantos cursos foram realizados por determinada gerência, ou quantos cursos foram realizados durante o ano. Ambos indicadores são medidos a cada 
três meses. O gerente de DRH afirmou que eles são balizadores para 0 planejamento de recursos a serem investidos no próximo ano.

Tabela 2: Tabela de indicadores da Petrobras

\begin{tabular}{|c|c|c|c|c|}
\hline Política de Qualidade & Objetivo da qualidade & Indicador & $\begin{array}{c}\text { Unidade } \\
\text { de Medida }\end{array}$ & Meta \\
\hline \multirow{2}{*}{$\begin{array}{l}\text { Gerar e disseminar } \\
\text { conhecimento com } \\
\text { qualidade e aderência } \\
\text { ao Plano Estratégico e } \\
\text { ao Plano de Negócios e } \\
\text { Gestão da Petrobras }\end{array}$} & $\begin{array}{l}\text { Oferecer soluções } \\
\text { educacionais } \\
\text { aplicáveis à } \\
\text { companhia }\end{array}$ & $\begin{array}{c}\text { Índice de Aplicabilidade } \\
\text { dos Cursos da } \\
\text { Universidade Petrobras } \\
\text { (IACUP) }\end{array}$ & Percentual & $\geq 70 \%$ \\
\hline & $\begin{array}{c}\text { Manter a satisfação } \\
\text { dos participantes nos } \\
\text { eventos da UP acima } \\
\text { do nível mínimo } \\
\text { esperado } \\
\end{array}$ & $\begin{array}{l}\text { Índice de avaliação de } \\
\text { reação global dos } \\
\text { eventos }\end{array}$ & Nota & $\geq 4,5$ \\
\hline \multirow{2}{*}{$\begin{array}{c}\text { Utilizar os recursos } \\
\text { disponíveis com } \\
\text { eficiência, disciplina e } \\
\text { capital e otimização de } \\
\text { custos }\end{array}$} & \multirow{2}{*}{$\begin{array}{l}\text { Manter a realização } \\
\text { orçamentária dentro } \\
\text { do limite planejado }\end{array}$} & $\begin{array}{l}\text { Realização de operações } \\
\text { e custos totais (ROCT) }\end{array}$ & Percentual & $\begin{aligned} 90 \% & \leq \text { ROCT-RHUP } \\
& \leq 100 \%\end{aligned}$ \\
\hline & & $\begin{array}{c}\text { Realização de } \\
\text { Investimentos ( RI) }\end{array}$ & Percentual & $\begin{array}{c}90 \% \leq \text { RI-RHUP } \leq \\
100 \%\end{array}$ \\
\hline \multirow{2}{*}{$\begin{array}{c}\text { Valorizar as pessoas e a } \\
\text { qualidade de vida }\end{array}$} & \multirow{2}{*}{$\begin{array}{c}\text { Aumentar a satisfação } \\
\text { e o comprometimento } \\
\text { dos empregados }\end{array}$} & $\begin{array}{c}\text { Índice de satisfação dos } \\
\text { empregados }\end{array}$ & Percentual & $\geq 79 \%$ \\
\hline & & $\begin{array}{c}\text { Nível de } \\
\text { comprometimento dos } \\
\text { empregados }\end{array}$ & Percentual & $\geq 78 \%$ \\
\hline
\end{tabular}

Fonte: Documento Interno da Petrobras (2014)

Os indicadores de custo e investimento são os gastos ocorridos confrontados com o orçamento, ou seja, Real/Planejado. Investimento são todos os dispêndios financeiros para desenvolvimento de instalações e sistemas, os demais são considerados custos.

Os indicadores surgem de uma necessidade da organização de avaliar e mensurar sua atuação e correlacionar com o que é esperado dela. No próximo item será abordado o porquê da necessidade de avaliar as ações educacionais na Universidade Corporativa da Petrobras. 


\title{
4.2.3. Necessidade de avaliar ações educacionais
}

A necessidade de avaliar os programas educacionais oferecidos, segundo o gerente de $\mathrm{DRH}$ é algo natural ao conceito de Universidade Corporativa. A avaliação é importante para determinar a eficácia dos cursos realizados.

Indicadores que eram importantes para o Centro de Treinamento, como HHT e Participações, atualmente estão em segundo plano. O fundamental hoje, para a UP, é avaliar a reação, a aprendizagem, o impacto, para verificar se tudo o que está sendo exigido para o $\mathrm{RH}$, está sendo efetivamente entregue.

A coordenadora de Impacto informou que a metodologia de avaliação de impacto utilizada proveio da adaptação de Palmeira (2012) e dos métodos já existentes.

\begin{abstract}
A metodologia que utilizamos foi adaptada (...) pela Cristina Palmeira, que já era uma profissional, tinha livro escrito, tese e tal. Ela veio trabalhar na Petrobras. E em um determinado momento houve uma oportunidade de realizar um workshop com Jack Phillips. (...) ela fez uma adaptação do que acontecia na metodologia de avaliação de impacto à realidade da Petrobras. Começaram os pilotos em 2009 e a partir dai se estabeleceu o processo que é bastante valorizado e apreciado aqui na empresa.
\end{abstract}

Com o surgimento da Universidade Corporativa, tentou-se adaptar o que já era analisado no Centro de Treinamento a essa nova realidade. Foram implantados novos métodos de avaliação dos cursos oferecidos e uma análise estratégica dos resultados oriundos dos programas educacionais.

\subsubsection{Resultados das avaliações}

Os resultados obtidos nas avaliações, descritas acima, servem como insumos para a melhoria dos programas educacionais. Contudo, essa análise de melhoria não ocorre no setor de $\mathrm{DRH}$, que realiza as avaliações das ações educacionais. Segundo todos os entrevistados essa é uma atividade que cabe às Escolas da UP, que recebem todos os resultados das avaliações, analisam as mesmas e tomam as providências cabíveis.

Cabe ressaltar que não foi realizado contato com as Escolas, para investigar como é feita a análise dos dados das avaliações consolidadas pelo setor de $\mathrm{DRH}$ e a proposição de melhorias para os futuros programas educacionais; pois elas não fazem parte do público-alvo da pesquisa.

Semestralmente o setor de $\mathrm{DRH}$ se reúne entre si para analisar criticamente os indicadores de desempenho provenientes do período anterior. 
Nessas reuniões são apontadas ações de melhoria para o período o seguinte, e essas ações são incorporadas ao planejamento do setor de Desenvolvimento de Recursos Humanos. Essas melhorias estão ligadas às atividades de $\mathrm{DRH}$, que são a medição dos indicadores e o método de avaliação de reação e impacto dos programas educacionais. A análise dos resultados provenientes dessas avaliações, como já abordado, é de responsabilidade de outra unidade organizacional.

Então a gente trabalha em um contexto de planejamento associado ao próprio planejamento de $\mathrm{RH}$ pro ano seguinte. Esses índices fornecem o insumo para que baseado naquilo que foi planejado, melhorar nossa atuação ou incrementar a atuação no que a gente identifique que precise de um enfoque maior. 


\section{Conclusões e recomendações para novos estudos}

Esse trabalho teve como objetivo verificar o processo de avaliação dos programas educacionais realizados pela Universidade Corporativa da Petrobras, sugerindo melhorias a partir da leitura do modelo de avaliação de Kirkpatrick (2010).

Para alcançar o objetivo exposto, utilizou-se de pesquisa bibliográfica, a fim de abordar o que autores debatem sobre o tema estudado e servir de insumo para a análise do estudo de caso. Também houve uma pesquisa de campo, na qual foram realizadas entrevistas com o gerente de $\mathrm{DRH}$, gerência responsável por aplicar e consolidar os resultados das avaliações, e a equipe de avaliação de impacto. Complementando as informações obtidas no campo, realizou-se a pesquisa documental, com documentos empresariais, para a elaboração da análise proposta.

Após o estudo aqui realizado, os dados apontam que o planejamento dos cursos oferecidos na Universidade Petrobras não estão aderentes ao proposto por Chiavenato (2002). A listagem de cursos a serem ofertados é planejada antes do levantamento de necessidades de treinamento. A impressão é que o planejamento e o levantamento de necessidades de treinamento são desassociados, quando, na verdade, essas atividades deveriam ser dependentes. O motivo que talvez possa explicar tal fato é que o planejamento dos cursos ofertados é realizado no Sistema de Educação Petrobras, na UP, enquanto o levantamento das necessidades é feito pelas áreas de negócio da Petrobras, através do PDI.

A partir da análise das entrevistas realizadas, e considerando o referencial teórico adotado, é possível realizar algumas sugestões sobre a atuação da UP, visto que o próprio gerente de $\mathrm{DRH}$ relata que ela ainda tem características de um Centro de Treinamento. O motivo desse relato é devido à dificuldade da UP para priorizar a capacitação em competências estratégicas, devido o grande volume de capacitação de competências técnicas. Uma Universidade Corporativa, segundo Eboli (2010), deve atuar no sentido de associar a estratégia e o desenvolvimento dos funcionários, essa é sua função primordial, e 
por essa atuação, ela deveria ser considerada de grande importância para a organização.

Em relação ao modelo de avaliação utilizado, percebe-se que está aderente com os níveis 1, 2 e 3 de Kirkpatrick (2010), que são reação, aprendizagem e comportamento. Já os resultados, nível 4 de Kirkpatrick (2010), não é amplamente investigado. Há poucos questionamentos no formulário de impacto que reflitam os resultados provenientes das ações educacionais, logo, não é possível mensurar o retorno organizacional.

Sobre a avaliação de reação, propõem-se a entrega do formulário de avaliação no final do curso realizado. Dessa forma, estimulam-se as respostas de mais participantes, e a sua análise poderá refletir de forma mais adequada a realidade do curso analisado.

A respeito da avaliação de aprendizagem, sugere-se que as informações resultantes sejam compartilhadas com o setor de $\mathrm{DRH}$, pois é o setor responsável por aplicar as avaliações e consolidar os dados obtidos. Com essas informações, o DRH poderia correlacionar os resultados identificados com os das demais avaliações.

A análise de impacto é realizada na Petrobras como uma análise final do programa educacional ocorrido. Avaliando as perguntas, percebe-se que há muitos questionamentos sobre a satisfação do entrevistado em relação ao programa realizado. Esses questionamentos cabem à avaliação de reação.

Infere-se que, por não haver uma interligação entre as avaliações, a equipe de impacto, sinta a necessidade de saber a opinião do participante sobre o programa educacional, para que sirva de insumo para a análise conjunta com os resultados de impacto. Isso poderia ser eliminado, caso houvesse uma interdependência entre as áreas que avaliam e analisam os resultados das ações educacionais.

Outra sugestão para a análise de impacto é tentar conhecer o ambiente em que o entrevistado está inserido. Essa averiguação é útil para entender os motivos que levam a implantação ou não do conhecimento na execução das tarefas. Com essa análise também é possível verificar a necessidade de sensibilizar os gerentes para atuarem de outra forma com seus subordinados, dando-Ihes mais liberdade para exercer suas atividades e modificar a forma como atuam nelas.

Sugere-se também que tenham mais perguntas no questionário de impacto que averiguem os resultados organizacionais obtidos pelos cursos oferecidos. 
Para tal, seria importante identificar o objetivo do curso e averiguar se os participantes conseguiram mudar seu comportamento, a fim de atingir o objetivo proposto e trazer resultados para a empresa.

Para medir retornos como o aumento de produtividade ou melhoria na qualidade de vida no trabalho, sugere-se que seja realizada uma pré-avaliação que mensure a situação antes do curso a ser realizado, e uma pós-avaliação para identificar os possíveis ganhos organizacionais provenientes dos programas educacionais.

Também se faz importante a troca das informações obtidas nas avaliações entre os setores. Somente assim, é possível correlacionar as situações ocorridas, interligar os resultados das avaliações e entender o que pode ter dificultado ou estimulado uma situação. A partir dessa análise, tomar previdências para mitigar esses acontecimentos ou para que favoreçam a ocorrência dos mesmos.

Em relação aos demais indicadores, acredita-se que o desdobramento da política de qualidade em índices e metas a serem atingidas é de grande valor para a organização. Isso facilita a adequação das atividades de educação à estratégia organizacional, bem como percepção do que deve ser alcançado. Contudo, percebeu-se que essa informação não é divulgada amplamente para todos, pois fica em posse dos gerentes da UP.

Um dos pontos interessantes desse estudo foi perceber a dificuldade de implantar avaliação em educação corporativa que contemple os níveis de avaliação propostos por Kirkpatrick (2010). Também relevante é a dificuldade da empresa para identificar e mensurar o retorno organizacional proveniente das ações educacionais.

Além disso, a falta de integração entre as áreas que participam do processo de avaliação dos programas educacionais pode dificultar o processo de análise e proposição de melhorias para os cursos oferecidos.

Outro fato percebido foi que as ações da UP referentes à Educação Corporativa ainda tem características de um Centro de Treinamento. Ao invés de ações mais estratégicas, a Universidade Petrobras ainda tem uma atuação voltada para o operacional, causando assim uma confusão entre o papel que exercia como CT e o que deveria exercer como UC. 


\subsection{Sugestões e recomendações para novos estudos}

Para estudos futuros, sugere-se que o universo a ser analisado contemple as Escolas da Universidade Petrobras; pois são elas que analisam os resultados das avaliações das ações educacionais, implantam as possíveis modificações nos cursos e planejam os programas educacionais a serem oferecidos no próximo período.

Também seria de grande valia identificar a dificuldade inerente ao fato da avaliação e da análise dos resultados serem descentralizadas, ou seja, não ocorrem em uma mesma unidade organizacional. Abordar como as áreas contornam esse obstáculo e os impactos causados por não haver uma análise integrada dos resultados.

Por fim, sugere-se que se compare o modelo de avaliação da Universidade Corporativa da Petrobras com 0 de outras Universidades Corporativas, identificando as semelhanças e diferenças no processo. Confrontando os futuros resultados aos encontrados nesse estudo, pretende-se identificar o porquê a Universidade Corporativa da Petrobras oferece poucas ações educacionais frente à quantidade de capacitação oferecida nas unidades organizacionais; e analisar como está sua atuação como Universidade Corporativa em relação às demais a serem estudadas. 


\section{Referências Bibliográficas}

ALLEN, M.; MCGEE,P. Measurement and evaluation in corporate universities. New Directions for Institutional Research, no. 124, p. 81-92., Winter Periodicals, Inc., 2004.

ASSIS, M.T. Indicadores de Gestão de Recursos Humanos: Usando indicadores demográficos, financeiros e de processos na gestão do Capital Humano. Rio de Janeiro, Qualitymark, 2009.

BORGES-ANDRADE, J.E. Desenvolvimento de medidas em avaliação de treinamento. Estudos de Psicologia (UFRN), v. 7, p. 31-43. Edição Especial, 2002

CALDAS, J.N. DRH uma história de sucesso: Desenvolvimento de recursos humanos na Petrobras. Rio de Janeiro: PETROBRAS, 2013.

CHIAVENATO, I. Gestão de pessoas: o novo papel dos recursos humanos nas organizações. $3^{\mathrm{a}}$ edição, Rio de Janeiro: Elsevier, 2002.

Recursos Humanos: o capital humano das organizações. $7^{a}$ edição, Rio de Janeiro: Elsevier, 2009.

DIAS, C.A.F.; GUEDES, L.V. A avaliação de Resultados em Educação Corporativa: Um Estudo de Caso. In: XXXVII Encontro da ANPAD, Rio de Janeiro: ANPAD, 2013.

DIAS, Carolina Aparecida Freitas. Avaliação de resultados em educação corporativa: um estudo com as organizações que se destacam em gestão de pessoas. (Dissertação de mestrado) - Departamento de Administração da Faculdade de Economia, Administração e Contabilidade da Universidade de São Paulo, São Paulo, 2012.

EBOLI, M. Fundamentos e evolução da educação corporativa. In: Bayma, Fátima. Educação Corporativa - Desenvolvendo e Gerenciando Competências. São Paulo, FGV, 2005

Educação Corporativa no Brasil: Da Prática à Teoria. In: XXVI Encontro da ANPAD, Rio de Janeiro: ANPAD, 2004.

Fundamentos e evolução da educação corporativa. In: Eboli, M.; Fisher, A.L.; Moraes, F.C.C.; Amorim, W.A.C. (Org.) Educação corporativa: fundamentos, evolução e implementação de projetos. São Paulo: Atlas, 2010.

GIL, A.C. Gestão de Pessoas: enfoque nos papéis profissionais. $1^{a}$ edição, São Paulo: Atlas, 2007. 
JUNIOR, F.H. Avaliação dos resultados. In: Eboli, M.; Fisher, A.L.; Moraes, F.C.C.; Amorim, W.A.C. (Org.) Educação corporativa: fundamentos, evolução e implementação de projetos. São Paulo: Atlas, 2010.

JUNIOR, F.H.; DIAS, C.A.F; EBOLI, M.P. Avaliação de Resultados em Educação Corporativa: Análise dos Níveis de Avaliação de Kirkpatrick-Phillips e sua Relação com o Balanced Scorecard. In: XXXVII Encontro da ANPAD, Rio de Janeiro: ANPAD, 2013.

KIRKPATRICK, D. L.; \& KIRKPATRICKck, J. D. Como avaliar programas de treinamento de equipes: os quatro níveis. Tradução José Henrique Lamensdorf; revisão técnica Klalter Fontana. Rio de Janeiro: Senac Rio, 2010.

LOPES, N. V. Educação corporativa: Estratégias e desenvolvimento e implementação de modelo. In: Bayma, Fátima. Educação Corporativa Desenvolvendo e Gerenciando Competências. São Paulo: FGV, 2005

MARINELLI, M. Educação Corporativa: um estudo sobre modelos de avaliação de programas. Fortaleza: Editora UFC, 2007

PALMEIRA, C. Avaliação de Resultados em Educação Corporativa. In: RAMAL, A. (Org.) Educação corporativa: como implementar projetos de aprendizagem nas organizações. Rio de Janeiro: LTC - Livros Técnicos e Científicos Editora Ltda., 2012

PEREIRA, C.S. Educação Corporativa na Era do Conhecimento. In: SILVA, R.V.; NEVES, A. (Org.) Gestão de Empresas na Era do Conhecimento. São Paulo: Serinews Editora Ltda, 2004

PHILLIPS, J. J. Measuring ROI in the public sector. ROI INSTITUTE, 2007

VERGARA, S. C. Projetos e relatórios de pesquisa em administração. 6. ed. São Paulo: Atlas, 2005. 


\section{Apêndice 1 - Roteiro de entrevista - Gerente}

1. Como são planejados os programas de treinamento? Como é identificada sua necessidade? Existe algum tipo de LNT? (Levantamento de necessidades de treinamento)

2. Qual o critério para que sejam requisitados os serviços de educação?

3. Existe algum PDI (plano de desenvolvimento individual) anual? Ou algo semelhante?

4. O conceito de competências é relevante no momento de montar a grade de treinamentos dos empregados?

5. Como é realizada a avaliação das ações de treinamento na Universidade Petrobras?

6. Como é o processo de treinamento da empresa? O treinamento é centralizado na UP ou há outras iniciativas por setor? Os setores têm independência para ofertar cursos ou treinamentos para seus empregados sem informar à UP? Há um orçamento anual para os treinamentos? A UP possui metas a serem atingidas anualmente? Como são definidas essas metas?

7. Quais são os tipos de treinamento que são fornecidos (comportamental, técnico) se todos são obrigatórios, se são eletivos?

8. Há indicadores de treinamento? Como HHT (homem hora treinamento), custo dos treinamentos? Qual a periodicidade desses indicadores (mensal, anual...)? São aplicados a todos os tipos de treinamento?

9. Como surgiu a necessidade de avaliar as ações da UP?

10. Como é avaliado se a Educação Corporativa está auxiliando a organização a atingir seus objetivos? Quais ferramentas ou sistemas são utilizados para isso?

11. É realizado controle dos custos diretos e indiretos relacionados ao programa? Explique.

12. Existe alguma ferramenta que permita avaliar as reações dos participantes? Explique. Existe algum indicador que mensure essa avaliação? 
13. Existe alguma forma de aferição da aprendizagem? Explique. Existe algum indicador que mensure essa avaliação?

14. É realizada alguma medição antes da execução do curso e depois do mesmo para a aferição da aprendizagem?

15. Existe alguma maneira de se avaliar se os programas promoveram as mudanças de comportamentos (habilidades e atitudes) a que se propuseram? Explique.

16. Existe uma maneira de se identificar se o que foi aprendido no programa está sendo aplicado no trabalho? Explique. Existe algum indicador que mensure essa avaliação?

17. De que forma é avaliado se a mudança de comportamento no trabalho está provocando mudanças no funcionamento da empresa? Existe algum indicador que mensure essa avaliação?

18. Como é o processo para realizar essas avaliações? Há alguma relação entre os tipos de avaliações propostas? Há alguma hierarquia, sequência, comunicação, troca de informação, entre elas?

19. As avaliações ocorrem em todos os cursos realizados? Se não, como é feito o processo de escolha desses cursos? Qual o motivo que leva a escolher uma amostra de cursos?

20. Para que servem os resultados obtidos dessas avaliações?

21. Como esses resultados auxiliam no planejamento dos treinamentos? $\mathrm{E}$ na melhoria, corte, mudança no conteúdo dos treinamentos? 


\section{Apêndice 2 - Roteiro de entrevista - Equipe Impacto}

1. Como é feita a avaliação de impacto? Existe algum indicador proveniente dessa avaliação?

2. Qual é a formula desses indicadores?

3. Há alguma correlação com os outros tipos de avaliação? (Reação e impacto) Há uma conversa, hierarquia com essas avaliações?

4. As avaliações ocorrem em todos os cursos realizados? Se não, como é feito o processo de escolha desses cursos? Qual o motivo que leva a escolher uma amostra de cursos?

5. Para que servem os resultados obtidos dessas avaliações?

6. Como esses resultados auxiliam no planejamento dos treinamentos? E na melhoria, corte, mudança no conteúdo dos treinamentos?

7. Como surgiu a necessidade de avaliar o impacto das ações da UP? 


\section{Anexo 1 - Formulário de Avaliação de Reação}

\section{AVALIAÇÃO DE CURSO PELO PARTICIPANTE}

Buscando melhorar cada vez mais a qualidade dos nossos serviços e, possivelmente, estender este curso a outros colegas, convidamos você a colaborar, respondendo às questões que se seguem. Sempre que possível, use os espaços para enriquecer sua opinião com comentários e sugestões. Muito obrigado.

$\mathrm{RH} /$ Treinamento

NOME DO CURSO / DISCIPLINA:

PERIODO DE REALIZAÇÃO:

NOME DO PARTICIPANTE (OPCIONAL):

\begin{tabular}{l|l} 
CARGO: & LOTAÇĀO:
\end{tabular}

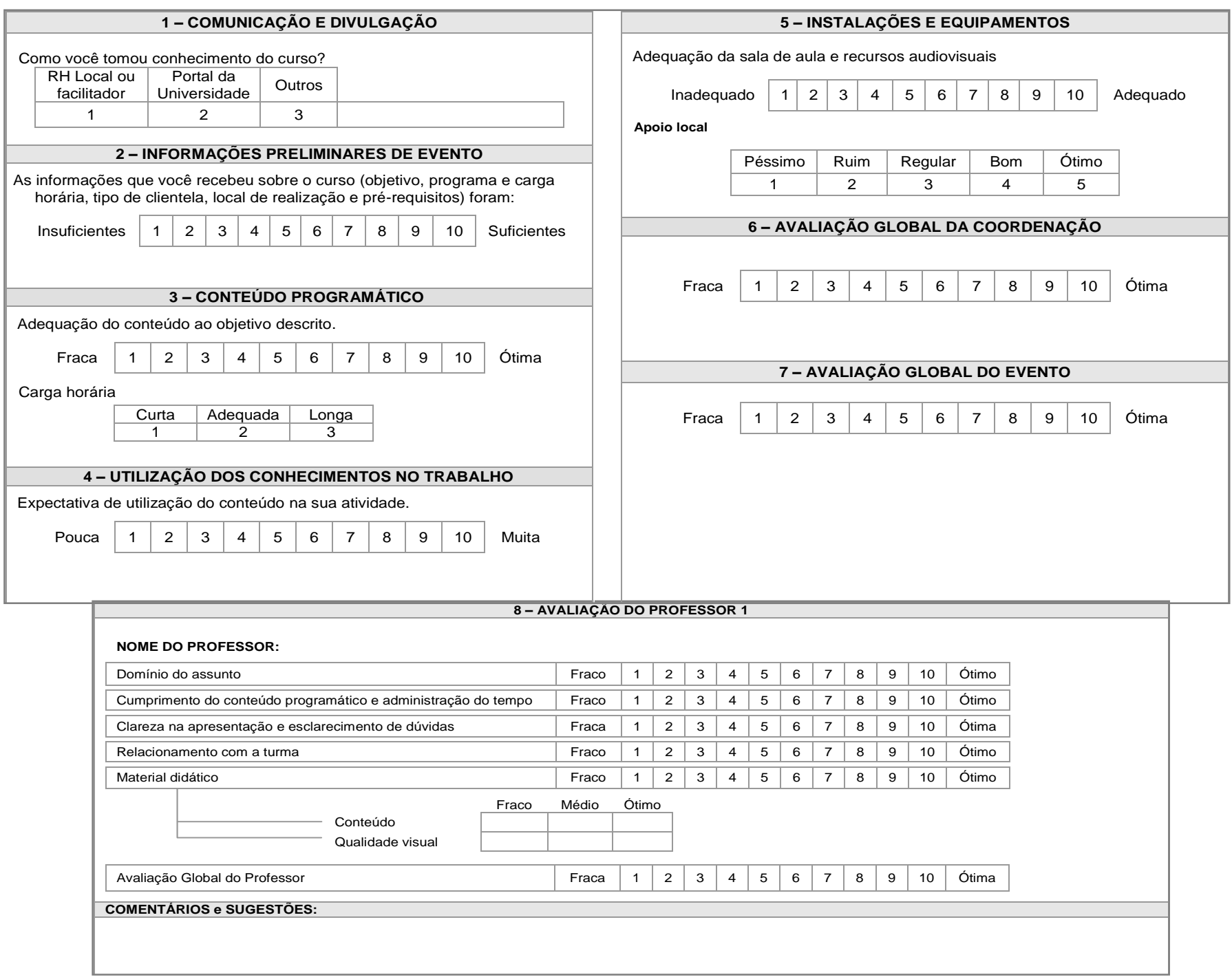




\title{
Anexo 2 - Questionário de impacto para participante
}

\author{
AVALIAÇÃO DE IMPACTO - EDUCAÇÃO CONTINUADA
}

Convidamos você a responder esta Avaliação de Impacto. Analise cada uma das questões e marque a alternativa que melhor representa sua opinião. Os campos comentários estão disponíveis para manifestar suas observações, conforme desejar.

Atenção: Ao finalizar o questionário não feche a janela, para que suas respostas sejam salvas no sistema é preciso clicar em "Submeter".

Agradecemos sua colaboração!

\section{$\mathrm{RH} / \mathrm{UP} / \mathrm{DRH} / \mathrm{PCDRH}$}

\section{INFORMAÇÕES FUNCIONAIS}

1.A função que você exerce na Companhia:

( ) Gerente

( ) Coordenador

( ) Supervisor

( ) Empregado de nível superior

( ) Empregado de nível médio

2.Tempo de Companhia:

( ) Até 5 anos

( ) 6 a 10 anos

( ) 11 a 20 anos

( ) Acima de 20 anos

\section{PERGUNTA FILTRO}

1.0 conteúdo programático do curso é coerente com as atividades que desempenho. 
Atenção: Caso a resposta seja "discordo", por favor, pular a pergunta 1 de seção "Impacto".
( ) Concordo
( ) Discordo

Nas questões a seguir, escolha a opção que representa sua resposta, apresentada em formato de escala de $0 \%$ a $100 \%$ onde $0 \%$ é o menor grau de concordância possível com a afirmação e 100\% o maior. Para as questões discursivas, responda à questão no campo disponibilizado.

\section{CURSO}

1.0 curso tem como objetivo "(INSERIR OS OBJETIVOS DO CURSO)". Em uma escala de $0 \%$ a $100 \%$, quanto ele atendeu esse objetivo?
( ) $0 \%$
( ) $10 \%$
( ) $20 \%$
( ) $30 \%$
( ) $40 \%$
( ) $50 \%$
( ) $60 \%$
( ) $70 \%$
( ) $80 \%$
( ) $90 \%$
( ) $100 \%$

2. Pensando no que aconteceu após sua participação, o curso está adequado às suas necessidades no trabalho? Em uma escala de 0\% a 100\%, como você pontuaria essa adequação?
( ) $0 \%$
( ) $10 \%$
( ) $20 \%$
( ) $30 \%$
( ) $40 \%$
( ) $50 \%$
( ) $60 \%$ 

( ) $70 \%$
( ) $80 \%$
( ) $90 \%$
( ) $100 \%$

3.Em uma escala de $0 \%$ a $100 \%$, quanto você considera que o curso é atualizado com a realidade Petrobras?
( ) $0 \%$
( ) $10 \%$
( ) $20 \%$
( ) $30 \%$
( ) $40 \%$
( ) $50 \%$
( ) $60 \%$
( ) $70 \%$
( ) $80 \%$
( ) $90 \%$
( ) $100 \%$

4.Que temas discutidos no curso mais se destacaram no seu desempenho profissional?
( ) Disciplinas/temas
( ) Disciplinas/temas

5.Em uma escala de $0 \%$ a $100 \%$, os temas abordados no curso foram significativos para melhorias no seu desempenho profissional?
( ) $0 \%$
( ) $10 \%$
( ) $20 \%$
( ) $30 \%$
( ) $40 \%$
( ) $50 \%$
( ) $60 \%$
( ) $70 \%$
( ) $80 \%$ 

( ) $90 \%$
( ) $100 \%$

6. Que sugestões você teria para o aprimoramento do curso?

7. Comentários adicionais sobre o curso.

\section{IMPACTO}

1.Em uma escala de $0 \%$ a $100 \%$ quanto do conteúdo e/ou prática tratados no curso você considera que se aplica no seu dia a dia?

Caso tenha respondido "discordo" na Pergunta Filtro pular esta pergunta.
( ) $0 \%$
( ) $10 \%$
( ) $20 \%$
( ) $30 \%$
( ) $40 \%$
( ) $50 \%$
( ) $60 \%$
( ) $70 \%$
( ) $80 \%$
( ) $90 \%$
( ) $100 \%$

2. Se você não tivesse participado do curso, quanto tempo você acredita que levaria para aprender na prática o que aprendeu no curso? Por favor, escreva sua resposta em formato de número inteiro (não sendo permitidos valores quebrados).

Escreva apenas o número de MESES. Ex: 1, 2, 3,.. 10,... Se tiver alguma informação qualitativa a acrescentar, utilize o campo abaixo.

\subsection{Justifique sua resposta.}

3. Já utilizou o material didático (apostilas, livros, apresentações, etc.) após o curso?
( ) Sim
( ) Não 
( ) Não se aplica

\subsection{Quais?}

4.O conteúdo aprendido no curso contribuiu na resolução de algum problema? Fez algo de maneira mais eficiente? Como o curso Ihe ajudou?

5.Você percebe no seu trabalho alguma melhoria em resultados, custos, utilização do tempo/recursos, decorrentes da participação no curso?

Seguem alguns exemplos:

- Diminuiu de X para Y a quantidade de ..., representando a economia de .;

- Percebi que..., pude solucionar o problema de ....;

- Implementei um novo projeto com...;

- Tive mais habilidade em... ;

- Mudei a forma de operar o ...;

- Realoquei um profissional jr. que estava insatisfeito;

- Tenho $Z$ empregados;........ a mais atingiram 100\% metas dos GD;

- Consegui motivar um empregado que tinha dificuldade com o trabalho;

- $O$ custo da solução caiu em $R \$$...;

- O tempo de processamento foi reduzido em X\% representando uma economia para a Companhia de $R \$$... .

6. Lembra de situações práticas onde aplicou o que aprendeu no curso? Exemplifique.

\section{CONCLUSÃO}

1.Estou satisfeito com a qualidade do curso realizado.

( ) Concordo totalmente

( ) Concordo parcialmente

( ) Não concordo nem discordo

( ) Discordo parcialmente

( ) Discordo totalmente

1.1.Comentários/justificativas:

2. Deixe aqui outros comentários que deseje manifestar sobre curso e também sobre esta avaliação. 


\section{Anexo 3 - Questionário de impacto para Gerentes}

\section{AVALIAÇÃO DE IMPACTO - EDUCAÇÃO CONTINUADA \\ Questionário para Gerentes}

1. O curso cumpriu o objetivo de acelerar a aquisição de competências necessárias à execução das atividades do empregado.

( ) Concordo totalmente

( ) Concordo parcialmente

( ) Não concordo nem discordo

( ) Discordo parcialmente

( ) Discordo totalmente

Comentários:

2. O curso está adequado às necessidades da sua Gerência.

( ) Concordo totalmente

( ) Concordo parcialmente

( ) Não concordo nem discordo

( ) Discordo parcialmente

( ) Discordo totalmente

Comentários:

\section{Obrigatória:}

3.Em relação aos conteúdos ministrados especificamente no curso (conforme Programa anexo), qual o percentual que você estima estar sendo aplicado nas atividades da sua Gerência e/ou na interação com outras Gerências da Companhia?
( ) $0 \%$ 

( ) $10 \%$
( ) $20 \%$
( ) $30 \%$
( ) $40 \%$
( ) $50 \%$
( ) $60 \%$
( ) $70 \%$
( ) $80 \%$
( ) $90 \%$
( ) $100 \%$

Comentários:

\section{OBRIGATÓRIA:}

4.A qualidade dos treinamentos conduzidos pela UP atende às necessidades e expectativas da gerência.

( ) Concordo totalmente

( ) Concordo parcialmente

( ) Não concordo nem discordo

( ) Discordo parcialmente

( ) Discordo totalmente

Comentários:

\section{OBRIGATÓRIA:}

Gostaria de vincular o seu nome às respostas?
( ) Sim
( ) Não 


\section{Anexo 4 - Avaliação de Impacto - Infográfico}

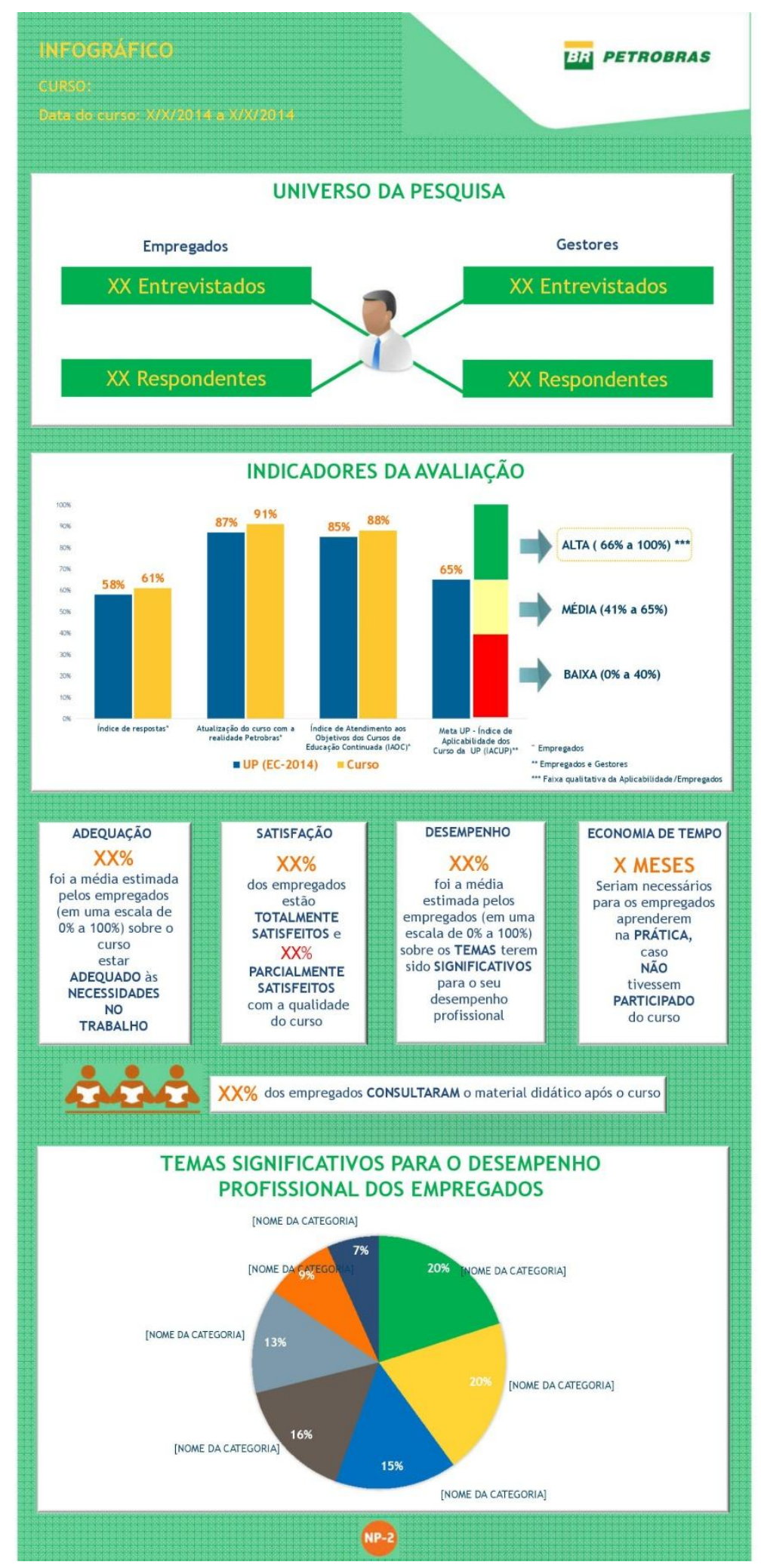

